The

\title{
Carl Beck
}

Papers

in Russian \&

East European Studies

Scott Brown

Number 2105

\section{Caricatures of Revolution: Slovak Political Cartoons in the Czechoslovak Spring}

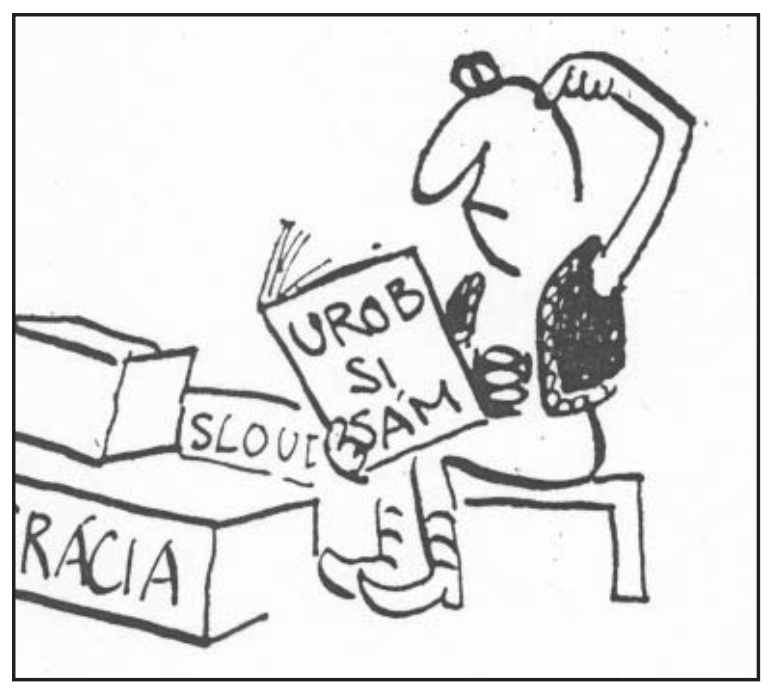


The

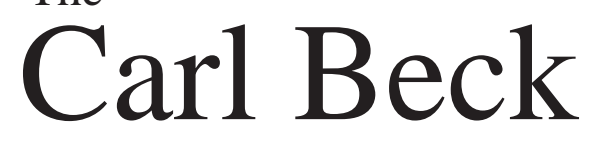

Papers

in Russian \&

East European Studies

Number 2105

Scott Brown

Caricatures of Revolution: Slovak Political Cartoons in the Czechoslovak Spring 
Scott Brown earned a Ph.D. in history in 2010 from the University of Washington. His dissertation, Socialism with a Slovak Face: The Slovak Question in the 1960s, offers a reexamination of the Czechoslovak Spring, arguing that Slovak nationalism played a vital role in sparking the upheaval, which began in Slovakia in the mid-1960s and achieved statewide dimensions only in early 1968. He is the past recipient of a Fulbright-Hays Doctoral Dissertation Research Abroad Fellowship, and has taught courses on modern European history, revolutions and the history of nationalism. He lives outside Washington, D.C.

No. 2105, November 2011

(C) 2011 by The Center for Russian and East European Studies, a program of the University Center for International Studies, University of Pittsburgh

ISSN 0889-275X

Image from cover: Cartoon by Milan Stano, "Do-it-yourself: Democracy, Federation, Slovakia,” Pravda, 9 August 1968. See page 49 for full cartoon.

The Carl Beck Papers

Editors: William Chase, Bob Donnorummo, Ronald H. Linden, Andrew Konitzer Managing Editor: Eileen O’Malley

Editorial Assistant: Julie N. Tvaruzek

Submissions to The Carl Beck Papers are welcome. Manuscripts must be in English, double-spaced throughout, and between 40 and 90 pages in length, including notes. Acceptance is based on anonymous review. Mail submissions to: Editor, The Carl Beck Papers, Center for Russian and East European Studies, 4400 Wesley W. Posvar Hall, 230 South Bouquet Street, University of Pittsburgh, Pittsburgh, PA 15260. 


\begin{abstract}
This paper probes Slovak cartoons of the 1960s for insight into Slovak attitudes toward national rights and democratic reforms during the Czechoslovak Spring, an upheaval in the spring and summer of 1968, when Slovakia experienced a rapid growth in the number of published cartoons and a new generation of Slovak cartoonists emerged. Slovak cartoonists in 1968 exhibited a sincere desire to see democratization come to fruition, yet they feared democratic reforms would come to naught, due either to internal resistance or external intervention. Moreover, Slovak cartoonists devoted considerable attention to Slovaks' demands for national rights and autonomy, including contemporary demands for the federalization of the Czechoslovak state into Slovak and Czech national republics. Their cartoons belie the stereotype of Slovaks in 1968 as narrowly focused on national issues such as democratization, showing instead how Slovak cartoonists regarded federalization as a democratic arrangement of Czech-Slovak relations and thus as an integral part of democratization in Czechoslovakia while also using humor and satire to remind their fellow Slovaks that federal reform was not tantamount to democratization.
\end{abstract}


Slovak cartoons - like other printed forms of political humor and satire- provided a visually arresting measure of the liberalization under way at the height of the Czechoslovak Spring in 1968. Though the Slovak media had already developed a reputation for being more daring than their Czech counterparts in what they would publish, Slovak cartoonists only gained the latitude to satirize domestic political targets once prepublication censorship ceased entirely in Czechoslovakia in March 1968. ${ }^{1}$ With the removal of prior restraints, Slovak cartoonists no longer pulled their punches, taking full advantage of the opportunity to skewer current events and public figures in a way that had been impossible throughout the Communist period. In addition to their newfound critical freedom, Slovak cartoonists gained a much wider audience as their work moved beyond Roháč (The Stag Beetle), a weekly Slovak humor magazine and the principal home for Slovak cartoons in the previous two decades, to the pages of more broadly disseminated newspapers and magazines. In terms of both content and readership, Slovak political cartoons flourished during the Czechoslovak Spring as never before-or since - in the Communist era.

However, the story of the renaissance of Slovak political cartoons in the Czechoslovak Spring is not simply a tale of cartoonists tackling political themes more directly or critically. True, Slovak satire from 1968 was noteworthy for its forcefulness and incisiveness. Yet these cartoons also deserve attention as a testament to the complexity of their creators' thinking, which reflected a mix of hopes and fears characteristic of the times. Some expressed a desire to see a more equitable national settlement for Slovaks, offering an endorsement of contemporary calls for a Czechoslovak federation. Far more captured fears about hard-liners, functionaries, and police officers resistant to political reforms. In the summer of 1968, much of the attention of Slovak cartoonists - and of the population of Czechoslovakia as a whole - shifted to the country's ostensible allies who began making menacing noises about the need to defend Czechoslovakia against antisocialist elements and counterrevolution. But the theme common to all of these kinds of cartoons was an abiding interest in the success of the reform movement and democratization.

In turn, the recurrence of democratic motifs in Slovak cartoons of 1968 challenges the stereotype of Slovaks as narrowly focused on satisfying their desire for greater autonomy within the Czechoslovak state by remaking it as a federation of two nation-based republics. Czech observers of the federalization debate in the spring and summer of 1968 often regarded the disagreements between Slovak and Czech reformers as a question of federalization versus democratization. Following the cues of these Czechs, many scholars have upheld a misleading national dichotomy in their studies of the Czechoslovak Spring. Though major studies of the Czechoslovak 
Spring acknowledge that Slovak reformers saw federalization and democratization as interconnected, many scholars nonetheless uphold a false dichotomy between the two objectives and portray this group of Slovaks as concerned principally with achieving a Czechoslovak federation, while reform-minded Czechs performed the heavy lifting of democratization. ${ }^{2}$ As a consequence, both popular and academic interpretations of the Czechoslovak Spring reproduce a stereotype of Slovaks as national minded and relatively indifferent to the tasks of democratization.

Cartoons offer some of the best evidence to debunk clichés about Slovak attitudes in the sixties. As Slovak political cartoons from the Czechoslovak Spring illustrate, Slovak attitudes from this period of upheaval were quite nuanced. During the tumult of 1968, cartoons captured Slovak cartoonists' trepidation that the current attempts at democratization would come to naught, due either to internal resistance or external intervention. This anxiety over the fate of the reform movement underscored the desire of cartoonists - and other Slovaks - to see democratization come to fruition. Even when Slovak cartoonists pictured national themes like federalization, their caricatures reflected a conviction that one of the essential tasks of democratization was to provide a fairer, more equitable resolution to the Slovak question. Indeed, Slovak cartoonists frequently spoofed national demands to remind their audiences that federal reform, though an integral component of democratic reform for Czechoslovakia, was not tantamount to democratization. Using humor and satire, Slovak cartoonists urge their fellow Slovaks not to allow their interest in federalization, seen as essential for a democratic resolution of the national question in officially bi-national Czechoslovakia, to cause them to lose sight of the threats to democratization. Cartoonists presciently warned that the creation of a federation without meaningful democracy would prove a hollow victory.

The genre of the political cartoon affords unique insight into the thinking of elites and their efforts to influence public opinion in such times of political and social upheaval. Cartoonists, like other social critics, thrive during moments of reform and unrest. Crisis upsets previously ascendant values and attitudes, creating an opportunity for cartoonists and other cultural elites to propose new worldviews and visions for the future. ${ }^{3}$ The medium of caricature, which exaggerates selected features to absurd and grotesque extremes in order to reveal some previously hidden or obscured truth, enables cartoonists to call attention to the problems they perceive in the existing society. Moreover, the creative possibilities of cartooning also provide a means for the caricaturist to propose solutions to these problems, and to present a picture of society transformed. Through their choice of subject and style of caricature, cartoonists model alternative values and worldviews in support of these 
fledging revolts. In turn, cartoonists use visual imagery, color, and other techniques to elicit a visceral reaction from their readers, whom cartoonists seek to provoke in a way that gives their art and its message greater impact in such uncertain times. ${ }^{4}$ The publication and dissemination of cartoons in mass media extends this influence by fostering a kind of imagined solidarity among their consumers, who constitute a community united in their shared encouragement to identify with the cartoonist's vision of an alternative society and its different values. ${ }^{5}$

This study is based on an examination of hundreds of published cartoons from the entire period of upheaval. I explored a wide range of Slovak (and Czech) periodicals published throughout the 1960s. Most of these cartoons appeared in newspapers and magazines with extensive circulations, though some came from less popular or niche publications. As a result, my analysis of Slovak political cartoons draws on a rather comprehensive survey of cartoons published in this era. The cartoons described and discussed in this study represent the most instructive and illuminating examples of Slovak political cartoons produced during the crisis years of the sixties.

\section{New Trends in Slovak Political Cartoons in 1968}

Remarking on the state of Slovak satire in February 1969, the Czech writer Milan Šimečka, who had lived in Bratislava for several years and soon became prominent as a dissident, praised Roháč for its role in resurrecting an art form that had gone missing in Czechoslovakia for twenty years. "The people who produce satire in Roháč were obviously prepared and had good timing last year when space opened up for political satire," he wrote in the Czech magazine Listy (Letters). The "cleverness, broadmindedness, ideological freedom and artistry" that came to life in the cartoons and written satire in Roháč commanded Šimečka's respect. Slovak satire had established itself on a "European level." Šimečka was so impressed with the political humor produced by Slovak cartoonists and other satirists that he argued they had developed satire into an art form - one of the art forms necessary for freedom. ${ }^{6}$

Indeed, the eruption of political and cultural liberalization in early 1968 at the height of the Czechoslovak Spring sparked an explosion in the development of Slovak political cartoons. Like other printed forms of satire, cartoons had experienced a similar period of rapid growth following the end of the Second World War, when several humor magazines began publishing, most notably Šibeničky (The Gallows), Šidlo (The Dragonfly), and Slimák (The Slug) and its successor, Kocúra Sršě̌ (Tomcat Yellow Jacket). But the Communist takeover in February 1948 brought an abrupt end to this proliferation of Slovak satire. Communist authorities shut down 
humor magazines, imprisoned some of their editors, and deprived cartoonists of their livelihood if they were unacceptable to the new Communist order. In 1948, the KSS replaced these newly defunct satirical publications with its own weekly humor magazine, Roháč, and gave it a de facto monopoly on published cartoons and satire - and on providing employment to aspiring Slovak cartoonists. ${ }^{7}$ But with the blossoming of the Czechoslovak Spring in 1968, Rohác lost its stranglehold on the genre as other Slovak publications started to print political cartoons. Slovak cartoonists had recently begun to publish their work elsewhere, beginning in other magazines, like the Slovak writers union weekly Kultúrny život (Cultural Life), and the Slovak youth union daily Smena (Change), before finding their way onto the pages of major Slovak dailies in 1968 such as the trade-union paper Práca (Labor) and even Pravda (The Truth), the organ of the KSS Central Committee. As a result, Slovak cartoons gained a significantly broader circulation. ${ }^{8}$ On this point, Slovak cartoonists arguably fared better than their Czech colleagues, since cartoons in Slovakia enjoyed greater penetration into popular media and had wider distribution than in the Czech Lands. ${ }^{9}$

Moreover, the expansion of political cartoons onto the pages of other publications broke Roháčs 's monopoly on the profession, giving several fledgling cartoonists a chance to make a name for themselves. In particular, Kultúrny život and Smena fostered the emergence of Stanislav (Stano) Kochan and Marián Vanek as leading figures in the profession. While older cartoonists like Viktor Kubal, Milan Vavro, and Ondrej Zimka were already fixtures at Roháč, a younger cohort of mostly twentysomething and often more daring cartoonists got their work into print elsewhere. Even though young caricaturists like Kochan and Koloman Leššo published occasionally in Roháč, they also gained a foothold at Kultúrny život. Similarly, Smena helped to launch the careers of Vanek, whom fellow cartoonist Kornel Földvári reverentially calls "the incorrigible Candide of our day," and Dušan Junek, who published more than four hundred cartoons in Smena alone from 1967 to $1969 .{ }^{10}$ Most of these up-and-coming cartoonists published their work in multiple Slovak outlets, as was the case with Milan Stano, who published memorable cartoons in 1968 in Smena, Kultúrny život and Pravda, though barely nineteen at the time.

While the sudden increase in the number of published cartoons (and active cartoonists) during the Czechoslovak Spring was remarkable, the qualitative shifts in the content of Slovak political cartoons were even more impressive. Prior to 1968, cartoonists could only get their creations into print if they toed the party line and upheld an appropriate ideological worldview. As a KSS Secretariat report from December 1958 explained, "The first task of the satirical journal is the education 
of its readers in the spirit of socialism. Implementation of this rule demands of the editors of 'Roháć' clarity of political aim." "ll As a consequence of this imperative to propagate the "spirit of socialism," cartoons published in the state-sanctioned press before the Czechoslovak Spring depicted the world in Manichean imagery. According to the dichotomy that marked Slovak cartoons, everything positive in the world was connected to communism, while all negatives were linked with the capitalist world and "the West."

Cartoonists helped to reinforce the image of the "enemy" by picturing capitalist political and business figures as hideous, even animalistic, in their greed for wealth. For instance, shortly after the American-backed Baathist overthrow and execution of Iraqi Prime Minister Abd al-Karim Qasim, who had nationalized the holdings of the British-owned Iraq Petroleum Company and maintained good relations with Communists at home and abroad, a cartoon appeared on the cover of Roháč titled "The Muezzin and the Faithful"' (figure 1). The cartoonist, Viliam Reichmann, depicts a Baathist (indicated by the name on his armband) Iraqi muezzin calling the faithful to prayer from atop an oil derrick instead of a minaret while the sun, emblazoned with a giant dollar sign, burns overhead. Observing this ritual from the surrounding oil field is an American, identifiable from the Stars and Stripes on his top hat, seated on a pipeline of the Iraq Petroleum Company carrying oil pumped from the muezzin's derrick. In a style characteristic of this period, Reichmann renders his American enemy as a grotesque caricature of Uncle Sam with avian features. Uncle Sam has long, skinny limbs and strokes his beard with spindly fingers. These elongated features contrast to Uncle Sam's large torso, and the tails on his pinstriped jacket evoke the tail feathers of a bird's plumage. Uncle Sam's most pronounced feature, an oversized, beaklike nose, completes the avian effect. In rendering Uncle Sam as a bird reminiscent of a hawk or vulture, Reichmann makes his point about the greediness of Americans who prey on foreign populations to slake their thirst for oil and material wealth.

In contrast to this negative image of the capitalist world, Slovak cartoonists rendered Communists as worthy of respect and admiration. And yet, the Communists who appeared in cartoons were anonymous archetypes rather than identifiable persons. Instead of portraying specific public figures, cartoonists depicted generic workers, soldiers, and officials who were heroic, strong, and determined, but nameless. The reason for this anonymity of subject was a de facto prohibition on cartoon versions of real people, no matter how flattering the caricature. Even a sympathetic caricature of a prominent figure could undermine the party's efforts to promote an ideologically appropriate worldview simply by giving such figures cartoonish fea- 


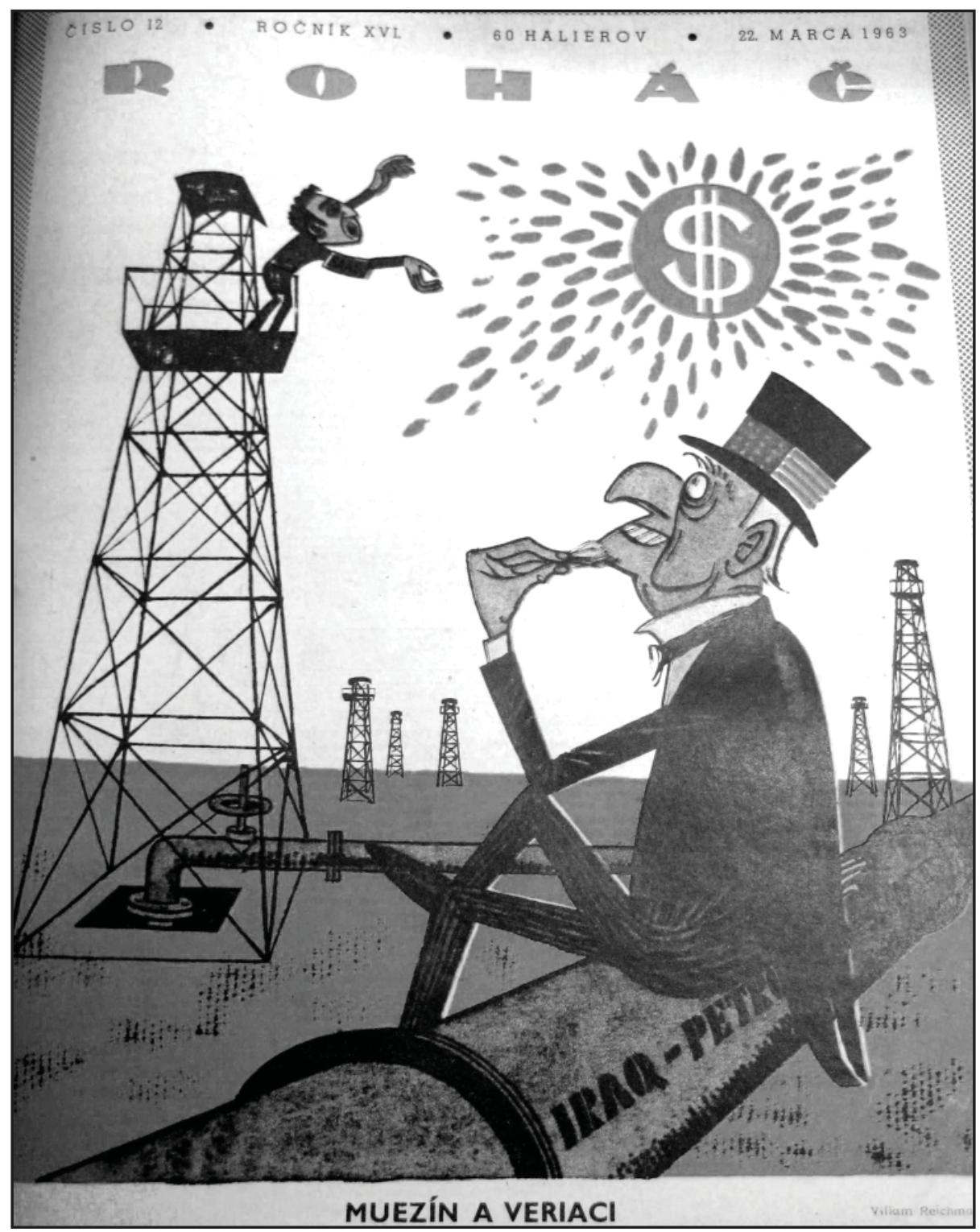

Figure 1: Viliam Reichmann, "The Muezzin and the Believer," Roháč, 22 March 1963. 
tures. As a result, cartoonists remained unable to publish caricatures of Communist politicians, both foreign and domestic, until the Czechoslovak Spring. ${ }^{12}$

The end of censorship in March 1968 brought an important change in this regard, since it allowed Slovak and Czech cartoonists to discard political dictates and represent the surrounding world however they saw fit. Slovak cartoonists used this newfound freedom to subvert and break the hegemony of the officially sanctioned worldview as they produced cartoons more satirical and critical of Czechoslovak politics. Their cartoons also began to make fun of Communist officials in general, and of specific politicians in particular. For the first time in twenty years, cartoonists could lampoon the country's leaders through caricature and present an image of Czechoslovak reality at odds with the party line. ${ }^{13}$

Moreover, this new artistic freedom brought certain stylistic shifts in how Slovak cartoonists portrayed their subjects. Whereas older cartoons exaggerated features to emphasize the contrast between friend and foe, the cartoons published in 1968 tended to make little or no distinction between these two binaries. ${ }^{14}$ Instead of relying on physical characteristics to make their point, Slovak cartoonists used clothing, accessories, and other imagery. Yet perhaps the most important way in which Slovak cartoons of the Czechoslovak Spring commented on current events was through their use of text, whether the dialogue of caricatured persons, words and phrases on walls and signs, or captions. Though several cartoons had no text at all or had meanings easily discerned without reading the words, many others relied on the included text to explain the cartoonist's point.

\section{Responses to Democratization, Spring 1968}

Initially, the shakeup of the leadership of the KSČ in January 1968 that launched the period of rapid reform most associated with the Czechoslovak Spring took Slovak cartoonists by surprise. Though the new KSČ first secretary, Alexander Dubček, was a familiar figure in Slovakia, where he had been KSS first secretary since 1963, and enjoyed a reputation as something of a reformer, the ouster of the previous KSČ first secretary, Antonín Novotný, and the installation of a reformer in his place was a stunning development. Equally shocking was the rapid push for reform and party-led democratization that followed Dubček's ascent. Stano Kochan captured this sense of astonishment in a cartoon that appeared in Kultúrny život on 15 March 1968, following on the heels of the KSČ leadership's decision to dismantle the system of censorship (figure 2). In the cartoon, an elderly woman in a nightgown is trying to rouse her husband, who has fallen asleep on a sofa while 


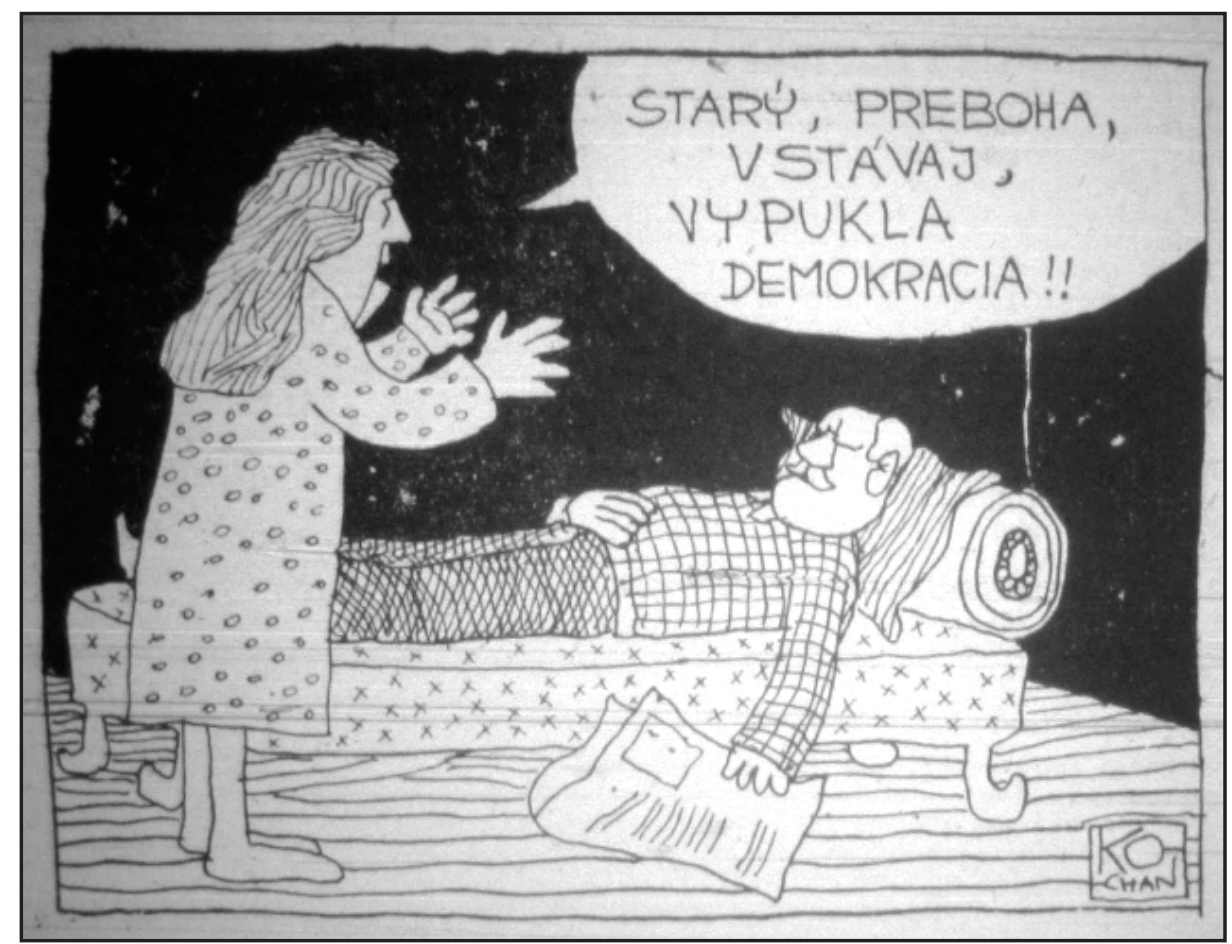

Figure 2: Stanislav Kochan, "For God's sake, wake up, old man, democracy has broken out!!” Kultúrny život, 15 March 1968, (c) 2010 Stanislav Kochan / Artists Rights Society (ARS), New York / LITA, Slovak Republic. 


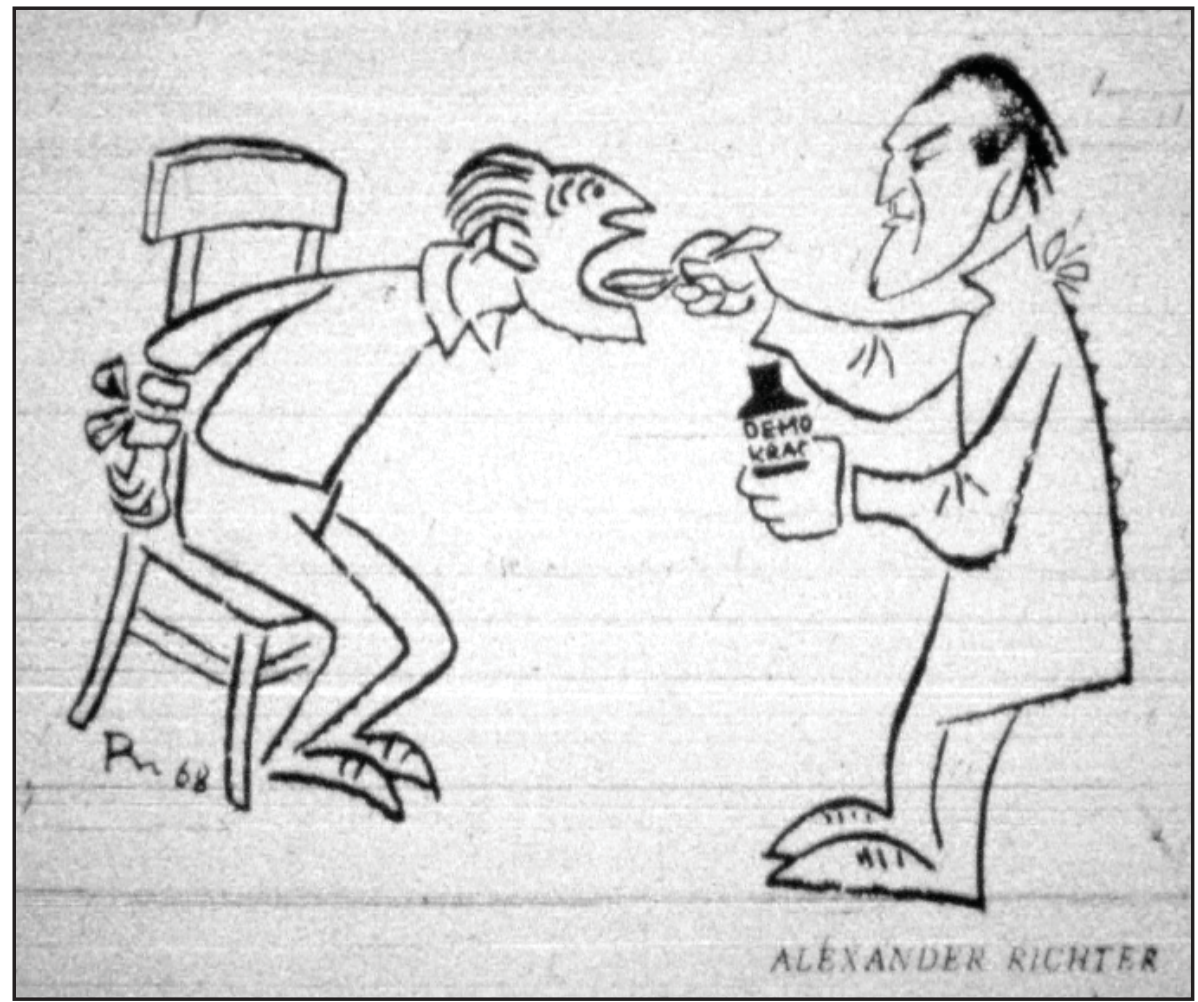

Figure 3: Alexander Richter, “Democracy,” Kultúrny život, 26 April 1968. 
reading a newspaper. She exclaims, "For God's sake, wake up, old man, democracy has broken out [vypukla]!!" The urgency of the woman's appeal-her tone and diction would be appropriate for sounding the alarm about a fire or war-conveys a sense of shock, but also the urgency of the moment. In Kochan's rendering, the citizens of Czechoslovakia could not afford to wait a single moment to respond to the unexpected "outbreak" of democratization in their homeland.

Yet Slovak cartoonists also used humor and satire to probe the meaning of Communist-led democratization. In a cartoon published in Kultúrny život in April 1968, Alexander Richter, one of the most senior Slovak cartoonists, depicts a doctor administering a spoonful of medicine from a bottle labeled "democracy" to a patient bound to a chair (figure 3). On one level, Richter's cartoon presents a healthy dose of "democracy" as a cure for Czechoslovakia's social maladies. According to this reading of the cartoon, Richter takes a good-natured swipe at the supporters and protagonists of the Czechoslovak Spring who regarded democratization as a panacea for all the ills afflicting the country. However, Richter's cartoon also raises questions about the desirability of elite-driven democratization. Viewed from this perspective, the cartoon doctor functions as an authority figure who almost seems to be forcing democracy down the throat of a bound patient. The patient appears willing to take this medicine, but the restraints on his hands make it clear that he is in no position to choose. Consequently, this alternative reading of Richter's cartoon suggests that even if the people of Czechoslovakia want democratization, they remain in a position of subjugation and have little alternative but to accept the democracy proffered them from above.

A cartoon printed in Smena in May 1968 also employs humor to mock the notion that democratization could come from some higher authority. The cartoon by an unnamed artist pictures a perplexed chef poring over a cookbook as he complains to his colleague, "There's no recipe [recept] in here for democracy!?" (figure 4) Through wordplay — recept also means "formula"- the cartoon communicates its message that there is no script for democratization. Anyone hoping to learn democracy from a book, like the exasperated chef, was bound to wind up disappointed because democratization required creativity and improvisation. Like Richter, this unidentified cartoonist poked fun at the Czechoslovak Spring and at those who thought there were easy answers for democratization. And yet, the gentleness of this satire also attests to more general mood of optimism that pervaded the country. In previous years, Slovak cartoonists had not broached the subject of democracy, much less spoofed it. The Communist regime professed to be a "people's democracy." Any caricature of democracy and democratization threatened the hegemony of this worldview. Thus, 


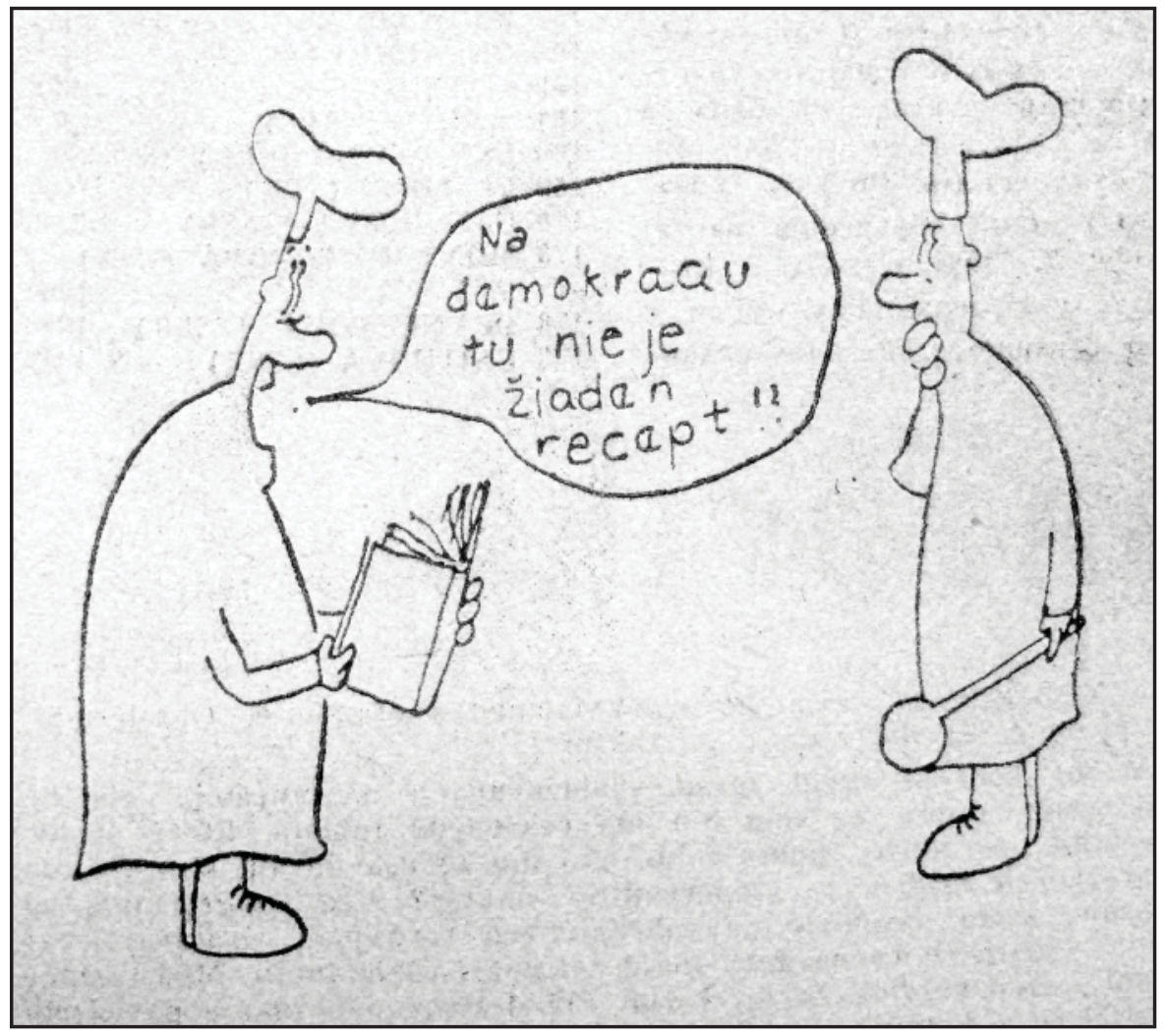

Figure 4: “There's no recipe in here for democracy!?” Smena, 9 May 1968. 
the appearance of democracy as a subject of cartoons, and as an object of satire, demonstrated how the party's control over cartoonists had slackened, signaling that democratization had become a distinct possibility, not just a distant dream.

Nonetheless, the beginnings of democratization seemed too good to be true. In mid-April, Kochan published a cartoon of two men gawking at a graffito that reads "demokraCIA" (figure 5). An adjacent caption reads, "Beware, comrades, this is how I see it!" The emphasis Kochan places on the final three letters in the Slovak word for democracy is provocative, and along with his explanatory comment, seems to imply that democratization in Czechoslovakia was so preposterous a notion that it could only be the product of American spies meddling in Czechoslovak affairs. At the very least, Kochan demonstrates his awareness that the country's Warsaw Pact allies were likely to regard the Czechoslovak Spring as nothing less than a CIA plot. Kochan's humor derives from its blatant absurdity: he obviously intends his audience to take this warning with tongue in cheek. After years of Communist propaganda urging Czechoslovak citizens to remain on the lookout for foreign conspiracies to sabotage socialism, it was appropriate - and hilarious - for Kochan to ape this officially encouraged vigilance by taking it to a grotesque extreme. His cartoon represented an effort to use humor to make sense of the surprising appearance of democratization in Czechoslovakia.

Yet Slovak cartoonists' surprise soon yielded to feelings of strangeness. During the spring of 1968, a common theme in Slovak cartoons was how surreal it seemed to watch the former forces of repression profess their support for democratization. For instance, a cartoon by Lubomír Mika features a hooded executioner exiting a dark room and dropping his ax as he rushes to announce, "Comrades-I am also for democratization!" (figure 6). In a similar vein, Kochan observed what odd bedfellows the reform movement had created. In a cartoon from April 1968, he portrays a policeman and prisoner walking arm in arm as the prisoner totes a sign that reads, "Long live our democracy" (figure 7). Yet it remained unclear to Mika, Kochan, and other Slovak cartoonists where the real loyalties of the police lay. Anton Soják published a cartoon in Práca skeptical of whether agents of the security forces could be trusted with democratization (figure 8). "Today's dilemma" facing a truncheonwielding policeman is Shakespearean: "To beat or not to be?" The existential question Soják poses for his policeman is even more poetic in the original phrasing, since the words for beat (bit') and be (byt') are Slovak homophones.

These cartoons capture the sense of both mistrust and disbelief their creators felt at seeing politicians, police, and other representatives of the Communist regime suddenly claiming to embrace reform and democratization. Such dramatic transfor- 


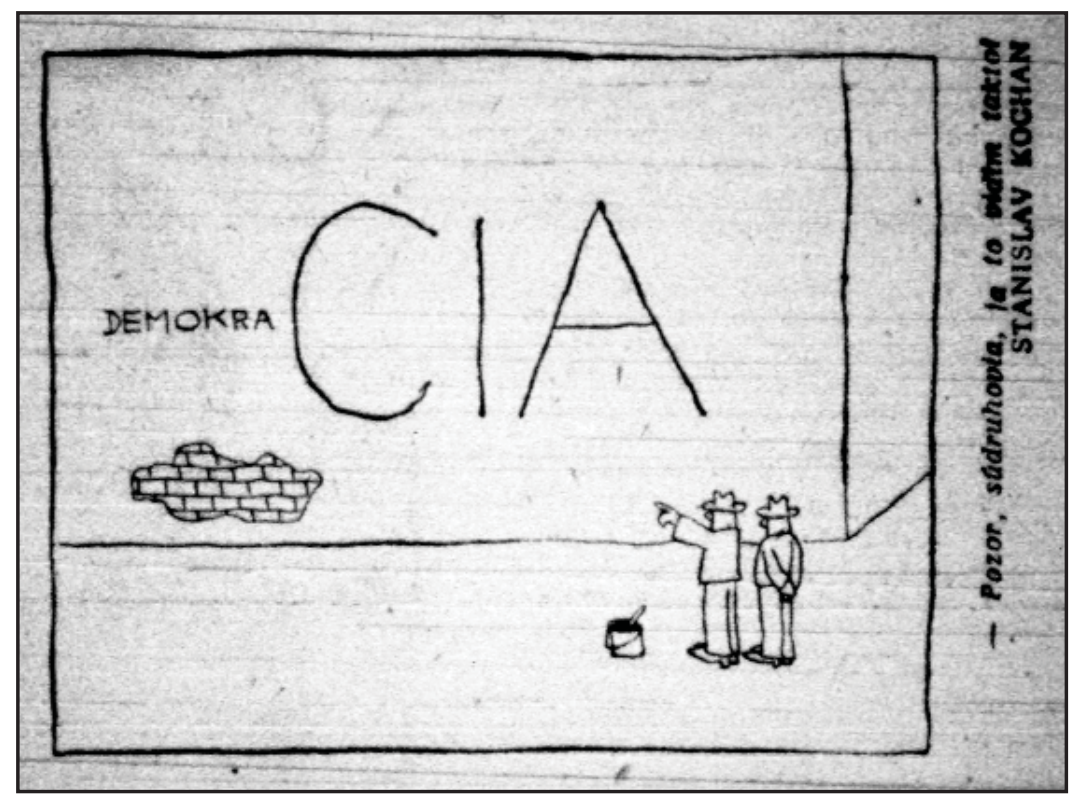

Figure 5: Stanislav Kochan, "Beware, comrades, this is how I see it!” Kultúrny život, 12 April 1968, (C) 2010 Stanislav Kochan / Artists Rights Society (ARS), New York / LITA, Slovak Republic.

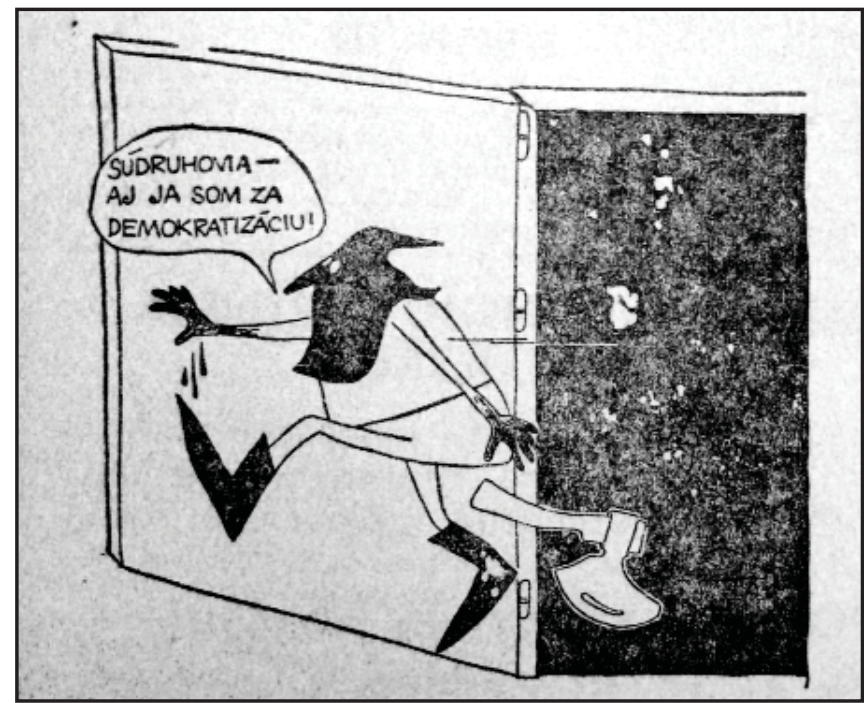

Figure 6: L'ubomír Mika, “Comrades - I am also for democratization!' Smena, 27 March 1968. 


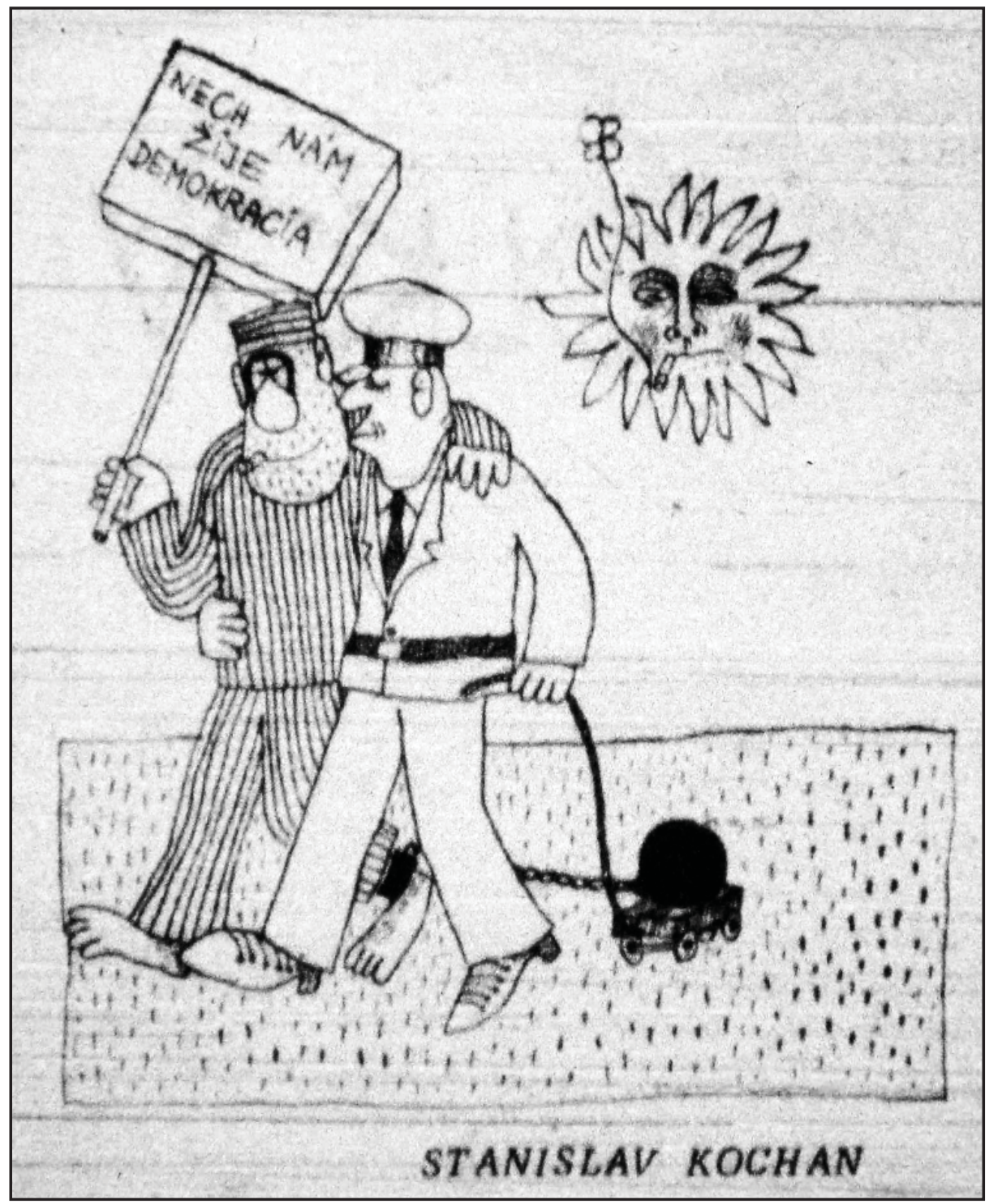

Figure 7: Stanislav Kochan, "Long live our democracy," Kultúrny život, 5 April 1968, (C) 2010 Stanislav Kochan / Artists Rights Society (ARS), New York / LITA, Slovak Republic. 


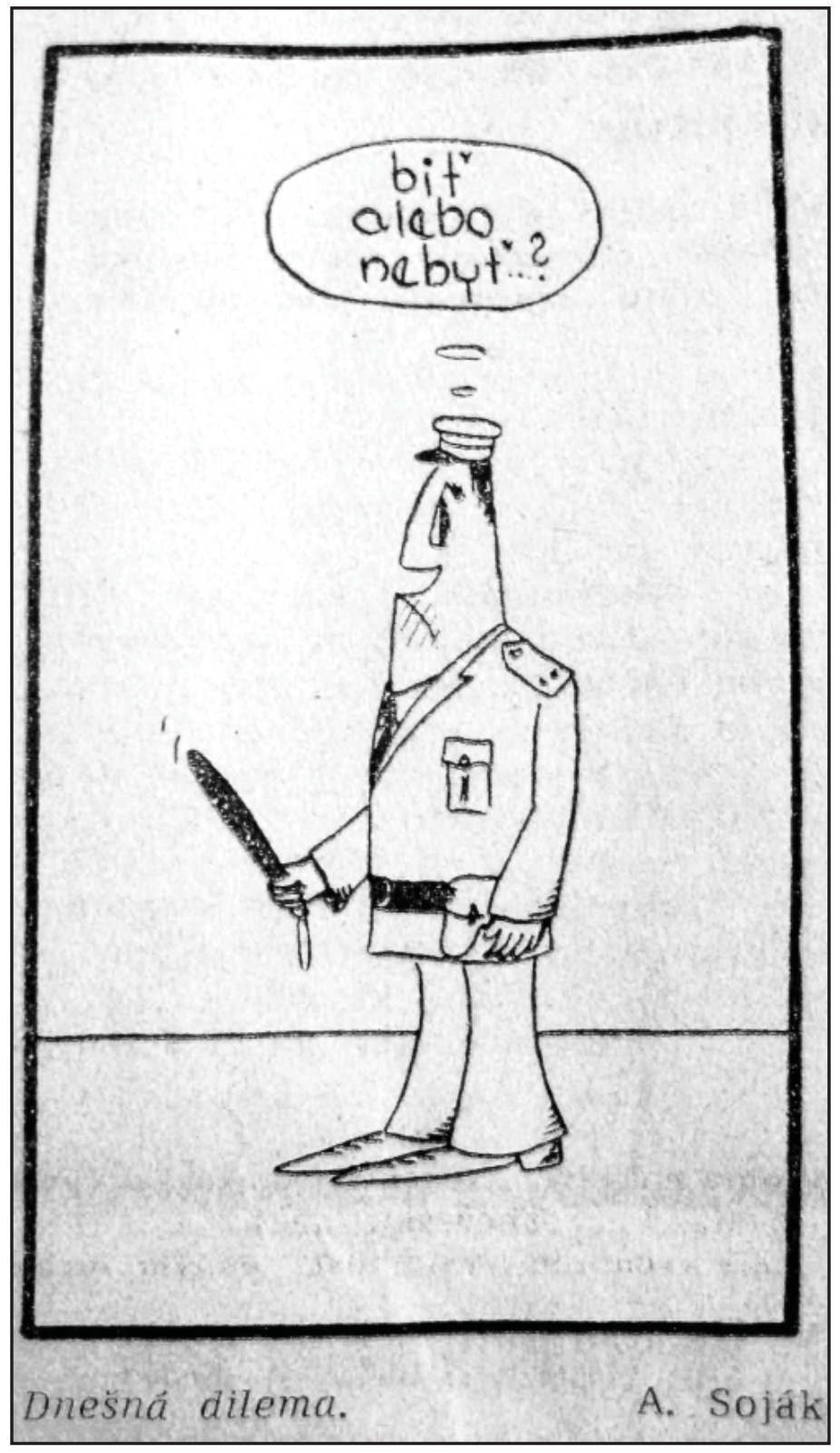

Figure 8: Anton Soják, "Today's dilemma: To beat or not to be?" Práca, 3 June 1968. 
mations appeared too good to be true, leaving Slovak cartoonists dubious. In one caricature from May 1968, Mika portrays the metamorphosis of a policeman who emerges from a lake carrying a truncheon, only to walk through a shower labeled "self-criticism" and emerge without his club and uniform (figure 9). Yet the cartoon also reads as an attempt to ridicule the policeman who thinks he can simply wash away the stains of his past crimes and misdeeds. Mika's use of color is quite arresting in conveying this point. In contrast to the black and white used for the rest of the cartoon, the lake and the residue it leaves on the policeman are red, evoking blood, which the policeman attempts to rinse off himself. In this way, Mika mocks the policeman who believes the Communist rite of self-criticism could have the same purifying, cathartic effect in a democratic context.

At the same time, Mika's cartoon functions as a warning to his Slovak audience to remain vigilant toward the police, who have not been called to account for their past crimes and in many cases still have blood on their hands, in spite of such efforts to "come clean." Indeed, a proposal in the spring of 1968 to require the hitherto anonymous police to wear badges with personal identification numbers garnered great sympathy from the public — and resistance from the police..$^{15}$ The skepticism of Mika's cartoon suggests a wider feeling of ambivalence as Slovaks welcomed these efforts to reform an oppressive system but remained leery of trusting the representatives of the Communist order, regardless of their efforts at self-criticism.

In a somewhat similar spirit, several Slovak cartoons suggested that Communist officials' embrace of democratization was superficial or a carnivalesque masquerade lacking substance and unlikely to last. Marián Vanek caricatures this tendency in a cartoon that shows a jacket labeled "Dogma" hanging from a rack as a man puts on a new jacket labeled "Democracy" and remarks aloud, "It's time I changed my coat" (figure 10). To Vanek, the Communists who wore their democratic credentials on their coattails were turncoats, raising the question of whether democratization was just a façade or would have real substance, at least where Communist officials were concerned. Likewise, a Milan Stano cartoon from June 1968 depicts a nameless functionary trying to choose between jackets with "Democrat" and "Dogmatist" written on the sleeves as he pores over a newspaper and asks aloud, "So, which coat should I wear today?" (figure 11). Like Vanek, Stano suggests the devotion of officials who wore their democratic commitment on their sleeves was purely cosmetic. Yet Stano's cartoon also offers an illuminating comment on the turbulence of the Czechoslovak Spring, when the day-to-day swings in the reform movement between hard-liners and reformers were so dramatic that ordinary bureaucrats needed a scorecard—or, 


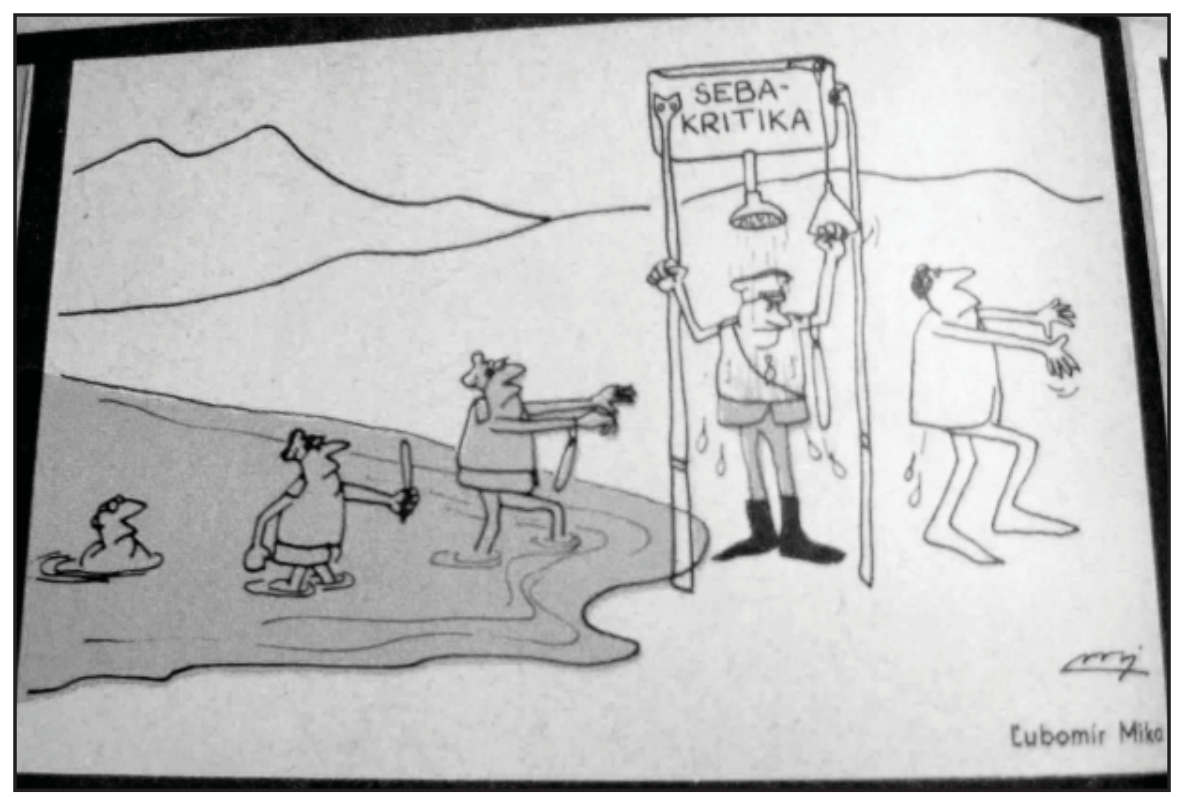

Figure 9: L’ubomir Mika, "Self-criticism,” Roháč, 15 May 1968.

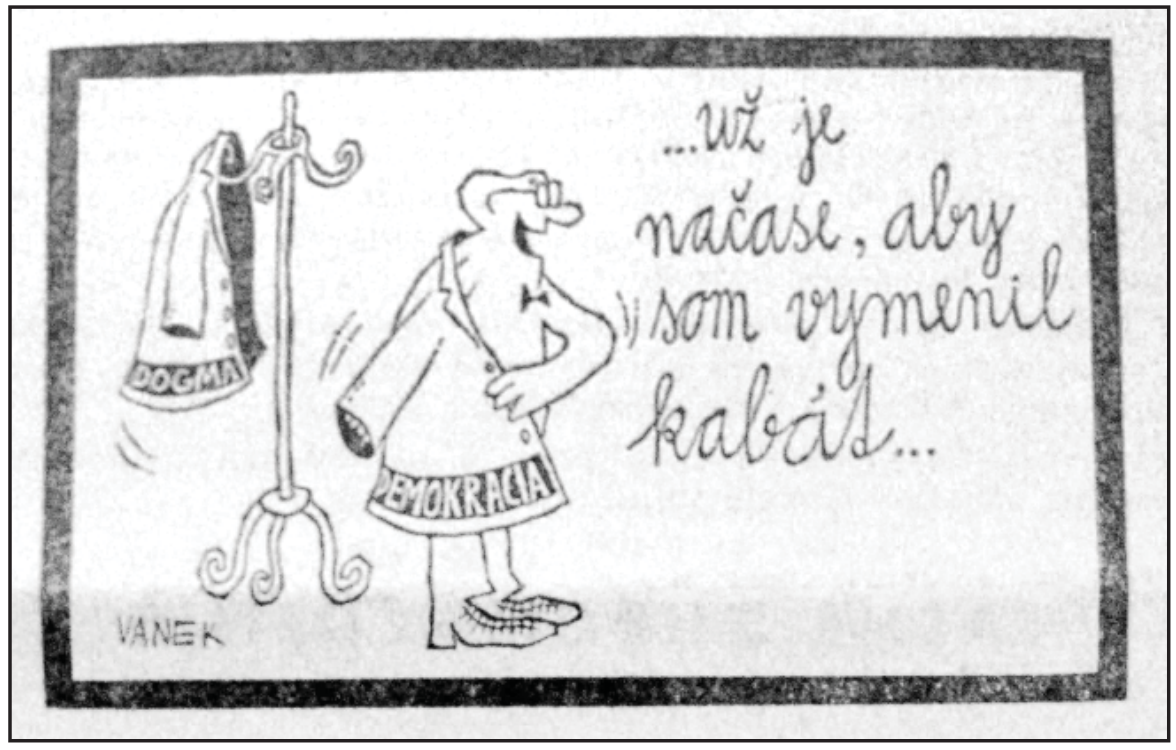

Figure 10: Marián Vanek, “. . . it’s time I changed my coat,” Smena, 27 March 1968, (C) 2010 Marián Vanek / Artists Rights Society (ARS), New York / LITA, Slovak Republic. 


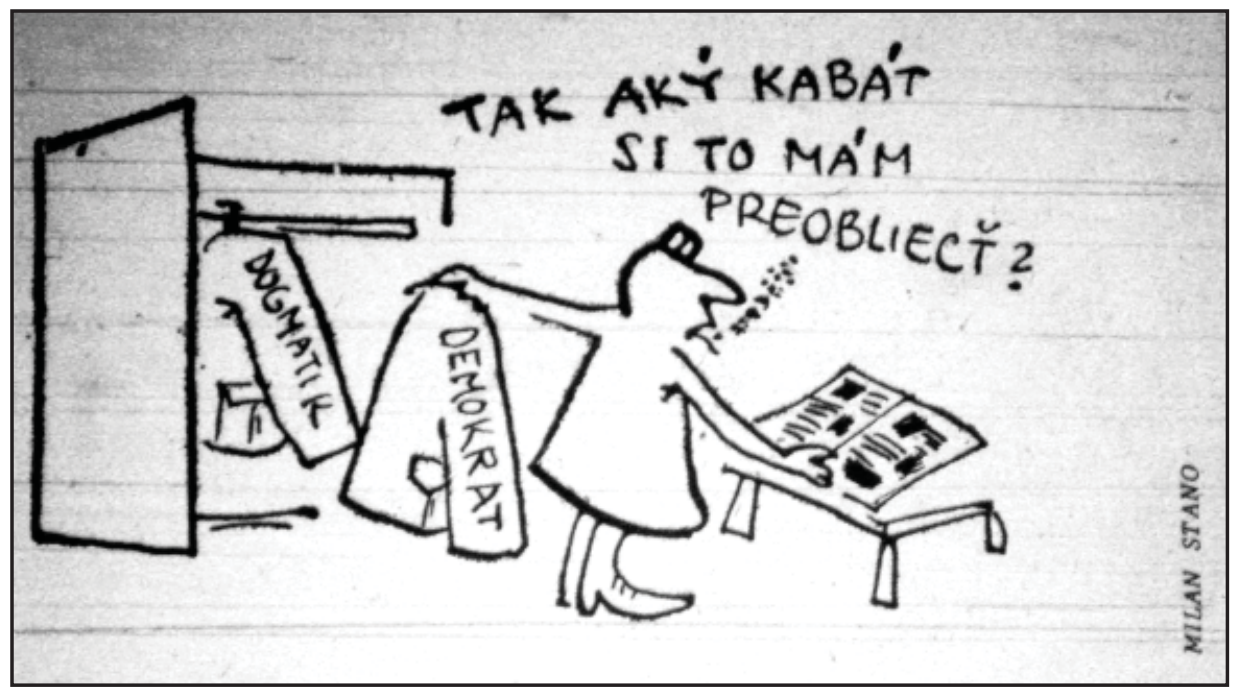

Figure 11: Milan Stano, “So, which coat should I wear today?” Kultúrny život, 28 June 1968.

in this case, a newspaper - to know which way the political winds were likely to blow on any given day.

Another topic that featured in several Slovak cartoons from the spring of 1968 was the opportunism of Slovak officials. In a cartoon by Viktor Kubal that ran on the cover of Rohác in April, two Slovak bureaucrats stand next to a railroad switch they have just used to divert a train carrying "criticism" toward Prague (figure 12). One of the officials remarks, "Good thing we switched it to Prague." The second official adds, "All's well for us Slovak functionaries." Kubal's cartoon provides a harsh comment on the resistance of Slovak officials, who deserved a trainload of criticism, to demands for them to own up to their mistakes. Rather than addressing their past failings, Slovak officials tried to redirect criticism away from themselves, preferring to deflect blame onto other, especially Czech, functionaries.

Kubal's cartoon also addresses the notion that arose after the Slovak National Council issued a formal appeal for a federation in March as an institutional expression of the national equality of Slovaks and Czechs, namely that Slovaks were less interested in democratization than Czechs were. Though Kubal later seemed to become a more nationalistic cartoonist, especially for the provocative way in which he portrayed Slovak grievances in the early 1990s, this cartoon from April 1968 challenges the notion that Kubal and other Slovak cartoonists placed more emphasis on Slovak rights than democratization during the Czechoslovak Spring. Kubal's cartoon 


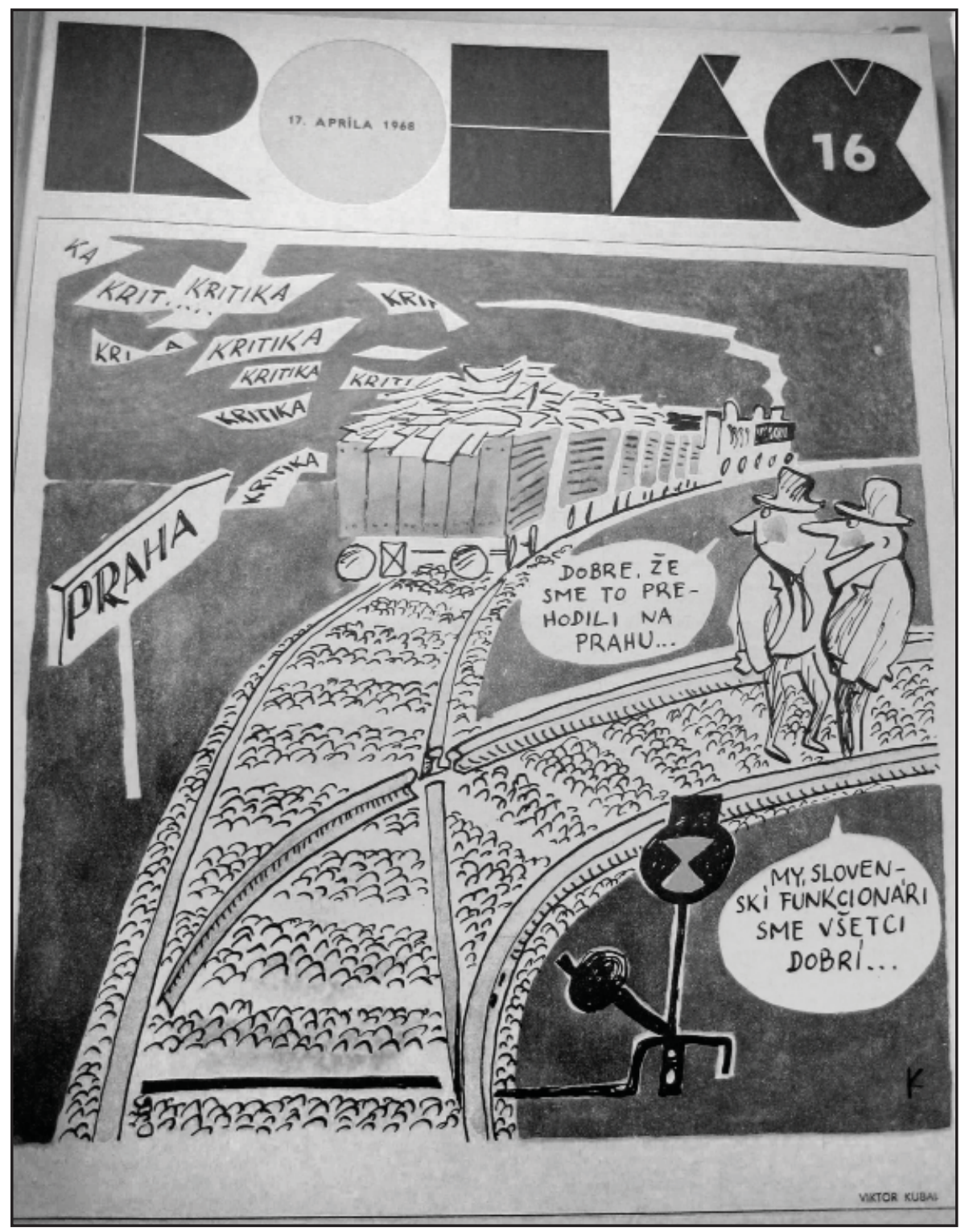

Figure 12: Viktor Kubal, "Good thing we switched it to Prague-All's well for us Slovak functionaries," Roháč, 17 April 1968. 
raises a concern shared by other Slovak cartoonists in 1968, namely their worry that Slovakia lagged behind the Czech Lands in democratization due to the resistance of Slovak officials. As Kubal shows, Slovak hard-liners hoped to shield themselves from liberalization by playing the national card, blaming Czechs-synonymous with "Prague" in this cartoon and in Slovak discourse more generally-for all the misfortunes that had befallen Slovakia. Though Kubal remained sympathetic to the nationally motivated complaints of his fellow Slovaks, his work from the Czechoslovak Spring counseled the need for Slovaks not to allow their national grievances to distract from the more important process of democratization. Slovak nationalism could be a hindrance to democratization, as Kubal warns, if Slovaks allowed their sense of national indignation to get in the way of rooting out compromised Slovak functionaries.

The efforts of Slovak officials to retain their positions also attracted the attention of Koloman Leššo. In a cartoon published on the cover of Roháč in May 1968, Leššo spoofs their self-preservation instincts (figure 13). The cartoon shows a hot air balloon struggling to stay aloft because its gondola, labeled "ZSF" with a footnote explaining the acronym stands for "Union of Slovak Functionaries" (Zväz slovenských funkcionárov), remains overloaded with functionaries, even with one official tumbling back to earth from the gondola. One man cries, "We're sinking!" A second replies, "Let's sacrifice another one!" This dialogue makes it apparent that the unfortunate official did not fall from the balloon by accident. Leššo caricatures the survival instincts of Slovak bureaucrats to reveal a deeper truth about the appalling lengths to which officials remained willing to go in order to save their own skins, even if it meant sacrificing one of their peers.

Fears of Slovak officials' resistance and conservatism persisted well into the summer of 1968. Vanek addresses this theme in a cartoon that appeared at the beginning of August, more than a month before the Extraordinary Fourteenth KSČ Congress scheduled for September, when the general expectation was that the party congress would remove the remaining hard-liners and conservatives in the party leadership in order to strengthen the position of the reformers and consolidate the gains of the Czechoslovak Spring. In the cartoon from Kultúrny život, Vanek pictures a reporter interviewing Alois Indra, a KSČ Central Committee member and notorious Czech hardliner expected to lose his position at the upcoming KSČ congress (figure 14). "Comrade Indra," the reporter inquires, "what would you do if the bell tolls definitively for conservatives?" Indra replies, "I'd go to Slovakia." With this caricature, Vanek offers a critical comment on the unwillingness of leaders within Slovakia to embrace liberalization, especially after Dubček had been co-opted into 


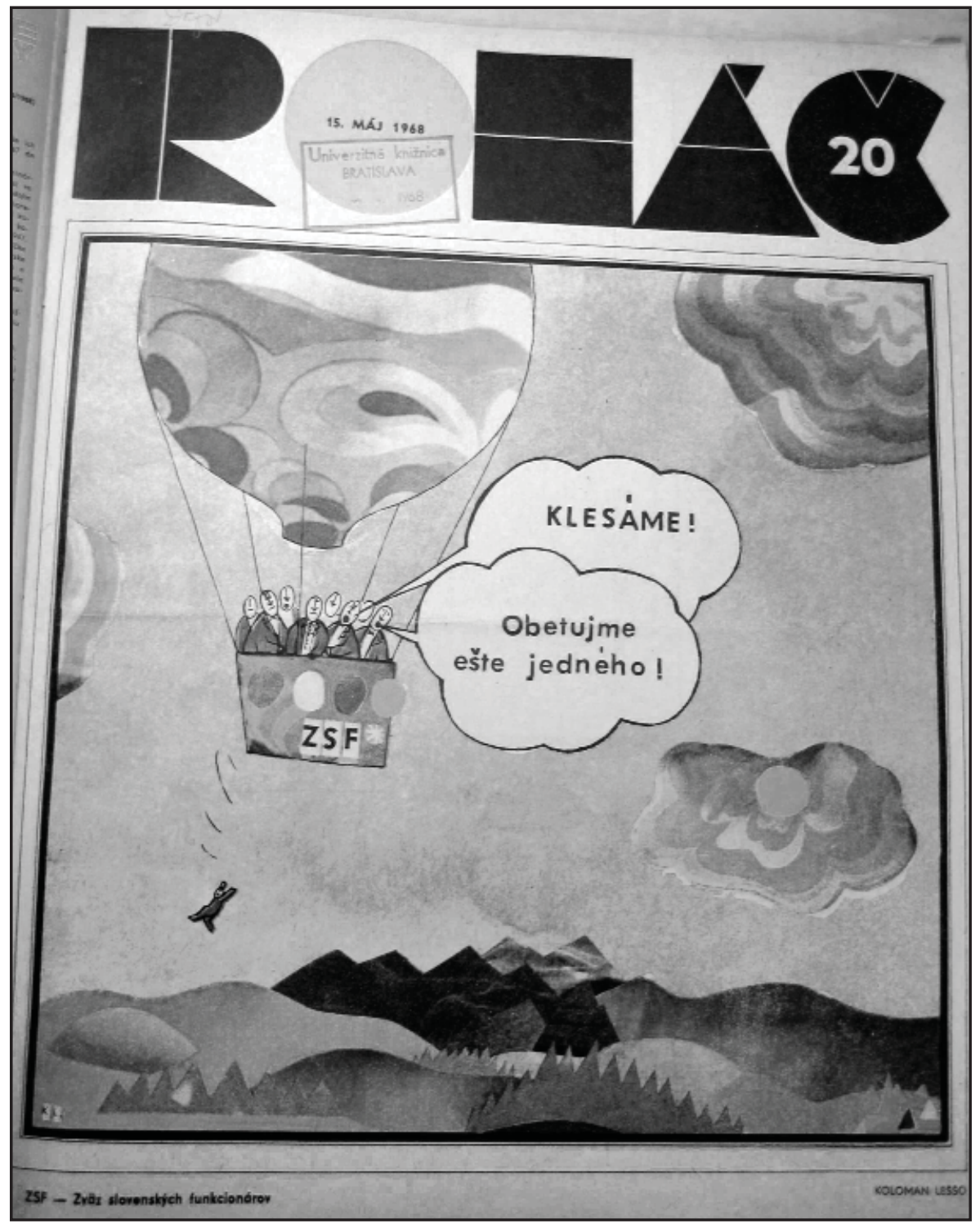

Figure 13: Koloman Leššo, “We're sinking! —Let’s sacrifice another one!” Roháč, 15 May 1968, @ 2010 Koloman Leššo / Artists Rights Society (ARS), New York / LITA, Slovak Republic. 


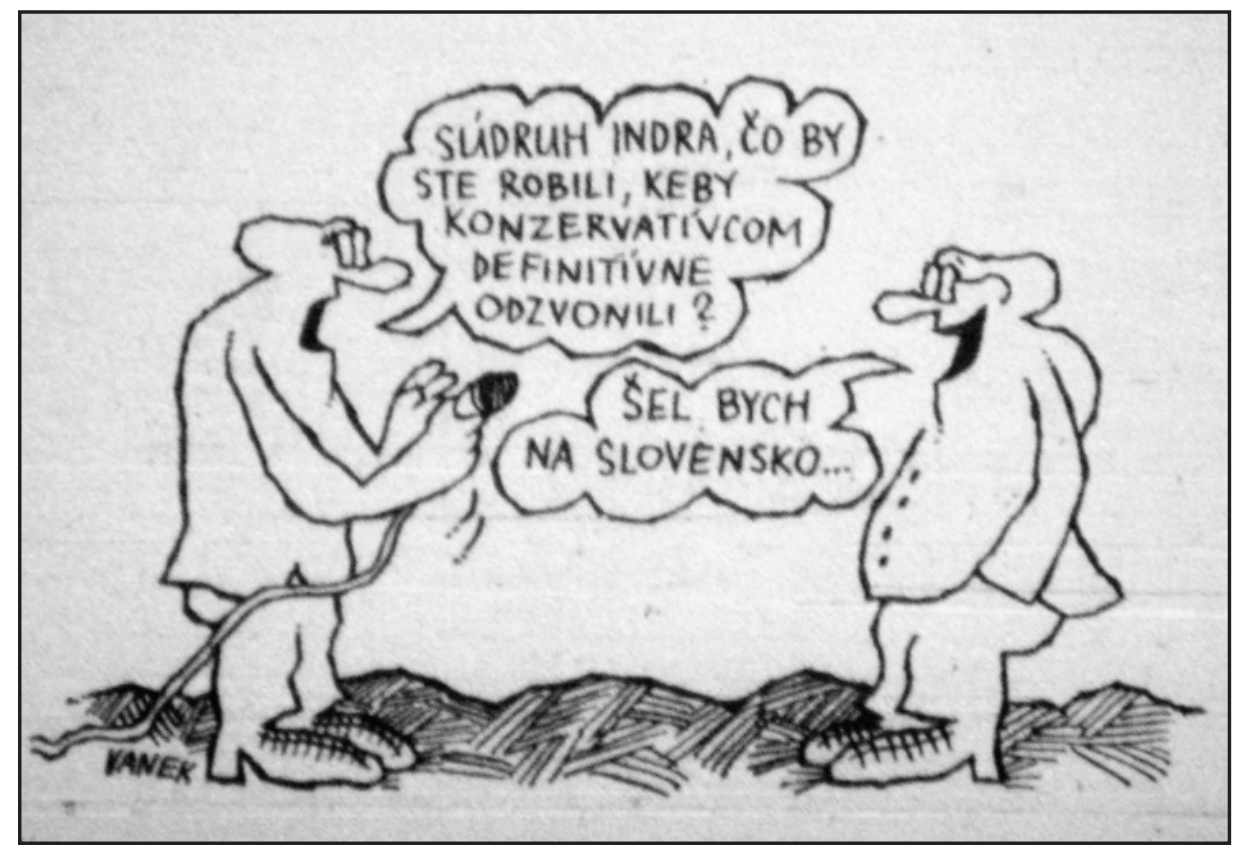

Figure 14: Marián Vanek, "Comrade Indra, what would you do if the bell tolls definitively for conservatives?-I'd go to Slovakia," Kultúrny život, 2 August 1968, (C 2010 Marián Vanek / Artists Rights Society (ARS), New York / LITA, Slovak Republic. 
the statewide party leadership in Prague. Vanek's cartoon likely struck a chord with the more pro-reform readership of Kultúrny život, since both Slovak and Czech protagonists of the Czechoslovak Spring feared Slovak hard-liners would pose an obstacle to democratization, at least in Slovakia, as they sought to cling to the power that came with their positions. One potential result, as Vanek observes suggestively, was that Slovakia threatened to become a reservation for defeated hard-liners, a kind of old conservatives home.

\section{Democratization in Jeopardy, Midsummer 1968}

Hopes for the success of the reform movement also surfaced in cartoons that addressed the prospect of a Soviet-led invasion of Czechoslovakia. As liberalization gained speed in the spring of 1968 and the KSČ's monopoly on power seemed more precarious, other members of the Warsaw Pact grew nervous and urged Dubček to stop the reform movement in order to ensure the survival of socialism in Czechoslovakia. When the Czechoslovak government declined an invitation to a meeting with five of its allies in mid-July 1968, the shunned members of the military alliance went ahead with their summit in Warsaw and intensified their pressure on Dubček and the KSČ leadership to put a halt to democratization. ${ }^{16}$ The saber rattling of Czechoslovakia's ostensible "friends" became a hot topic for public discussion-and for Slovak cartoonists. During the summer of 1968, the Slovak press published a series of cartoons trying to allay the fears of "the Five" that democratization had put socialism in danger in Czechoslovakia. These cartoons challenged the claims of Leonid Brezhnev and other Warsaw Pact leaders that Czechoslovakia had suffered an outbreak of "counterrevolution," which threatened to infect other Communist states. But these cartoonists also sought to dissuade "the Five" from intervening in Czechoslovakia. While these cartoons revealed the growing fear among Slovaks and Czechs that the Czechoslovak Spring might not last through the summer, the flip side of these fears - and the emotion that made such worries so terrifying - was a deep-seated hope that democratization would survive and continue.

The cartoonist most attuned to the heightened tensions within the Warsaw Pact at the time of the Warsaw meeting was Marián Vanek, who repeatedly aped the thinly disguised threats of "the Five" and captured the fear of an invasion he shared with his compatriots. In one cartoon, Vanek lampoons Soviet claims of Czechoslovak counterrevolution, showing five men crawling around an outline of Czechoslovakia as one exhorts the others, "Look around, comrades, bourgeois ideology has supposedly infiltrated us here" (figure 15). Vanek's depiction of five men is an unmistakable 
allusion to "the Five," but equally provocative was the interjection vraj (used in the sense of "allegedly" or "they say" to indicate hearsay), which suggests the "bourgeois ideology" threatening Czechoslovakia was just a delusion of "the Five." A second Vanek cartoon depicts a man telling a shadowy figure in a trenchcoat, "You need to stop this democratization, make some provocation" (figure 16). Literally the text says "democracy," which rhymes with "provocation" in Slovak. Vanek echoes this theme in a third cartoon, which shows a pair of workers chatting among themselves as one says to the other, "I'm still afraid that to secure the unity of the peace camp, we're going to have to put an end to this democracy" (figure 17). This comment evoked the paradox of the "peace camp" using violence to keep the peace, questioning the legitimacy of the Soviet Union and other Communist countries to claim leadership of the international peace movement. In turn, the cartoon functions both as a statement of Vanek's fear of the premature demise of democratization, and as his appeal to "the Five" to avoid such a disastrous step that would cause them to lose face.

In contrast to the years before 1968, Slovak cartoons from the Czechoslovak Spring were noteworthy for their direct, critical references to Czechoslovakia's Communist "friends," especially the Soviet Union. Vanek tried to discourage an invasion in a caricature of a medical exam room, using a patient as a stand-in for the Soviet leadership, whom Vanek addresses through the cartoon doctor: "Your fears about developments in Czechoslovakia are unfounded, Ivan Ivanovič. You can rest easily" (figure 18). Vanek's use of the patronymic name "Ivanovič," a linguistic convention found in Russian but not in Slovak, is a clear reference to the Soviet leadership and in particular to Brezhnev, who was fond of addressing Dubček as "Alexander Stepanovich." Thus, the cartoon seeks to allay the fears of the Soviet leaders and avert a military intervention.

Likewise, a pair of cartoons that appeared in Kultúrny život on 2 August, at the end of a three-day meeting of Czechoslovak and Soviet leaders, symbolized the strained connection between the two allies. The discussions, part of a last-ditch effort on both sides to prevent an invasion, had been held at Čierna nad Tisou, a railway junction in Eastern Slovakia near the Ukrainian border where trains between the two countries stop to switch to the appropriate railway gauge. ${ }^{17}$ The first of these cartoons, by Stano Kochan, shows mechanical hands stretching from two train engines passing on parallel sets of tracks (figure 19). One locomotive appears to travel westward on the narrow-gauge railway as its engineer looks forward. The engineer on the eastbound train - the wider gauge of the rails indicates its destination is the Soviet Union-looks back at the slipping connection. This strained contact epitomizes the tenuous grip Soviet leaders tried to maintain on Czechoslovakia, though it also 


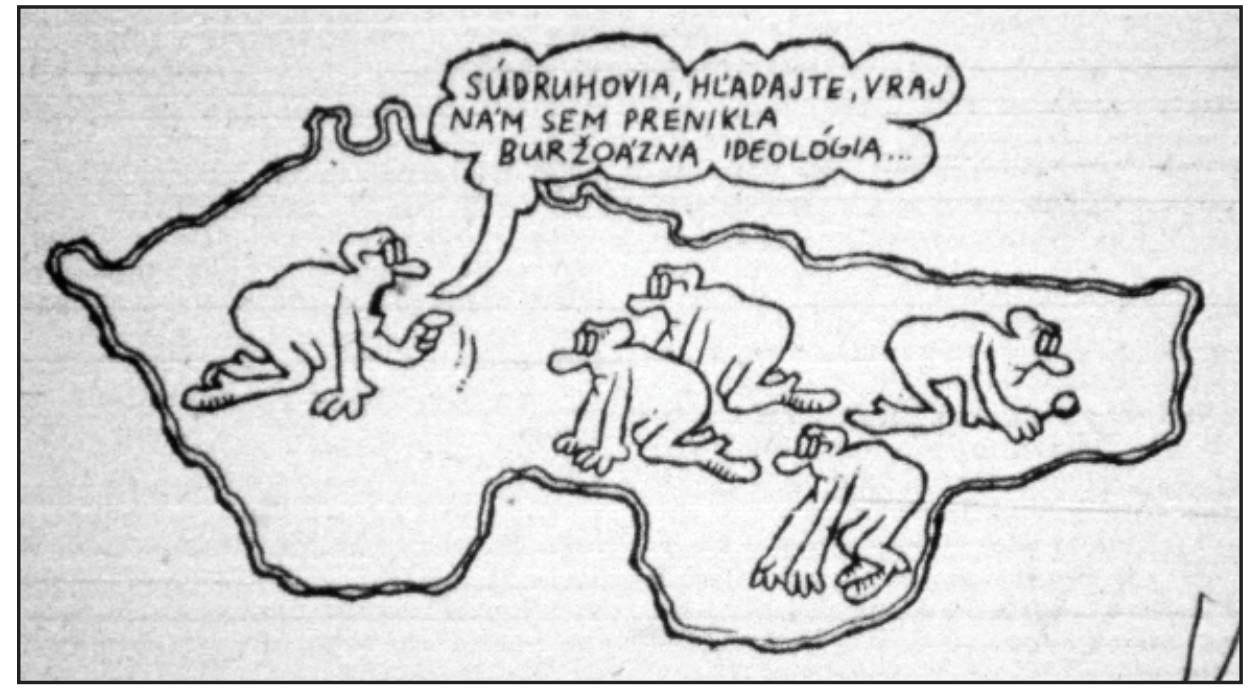

Figure 15: Marián Vanek, "Look around, comrades, bourgeois ideology has supposedly infiltrated us here," Kultúrny život, 12 July 1968, (C 2010 Marián Vanek / Artists Rights Society (ARS), New York / LITA, Slovak Republic.

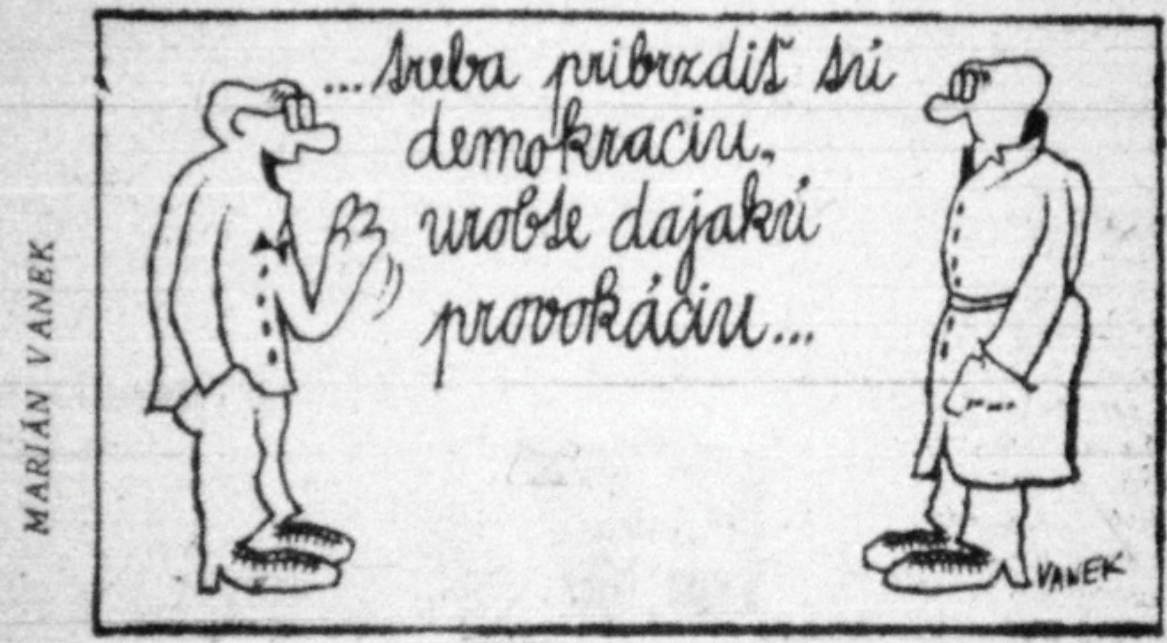

Figure 16: Marián Vanek, "You need to stop this democratization, make some provocation," Kultúrny život, 12 July 1968, (C) 2010 Marián Vanek / Artists Rights Society (ARS), New York / LITA, Slovak Republic. 


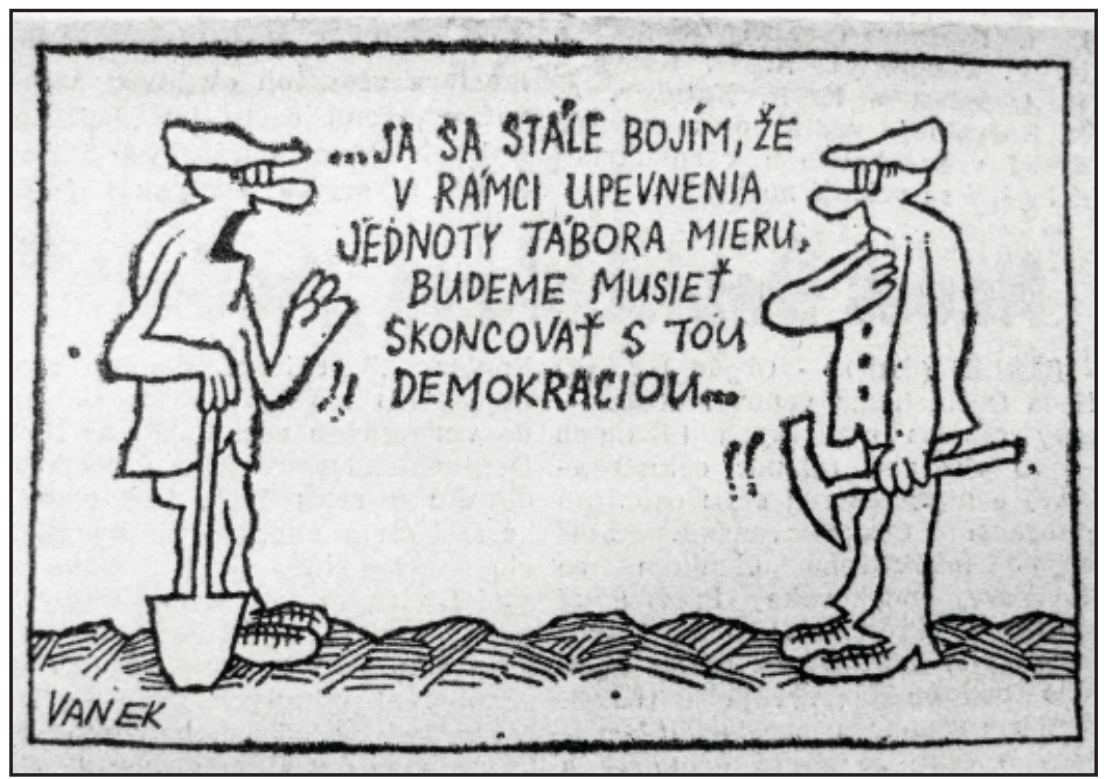

Figure 17: Marián Vanek, "I'm still afraid that to secure the unity of the peace camp, we're going to have to put an end to this democracy," Smena, 14 July 1968, (C) 2010 Marián Vanek / Artists Rights Society (ARS), New York / LITA, Slovak Republic.

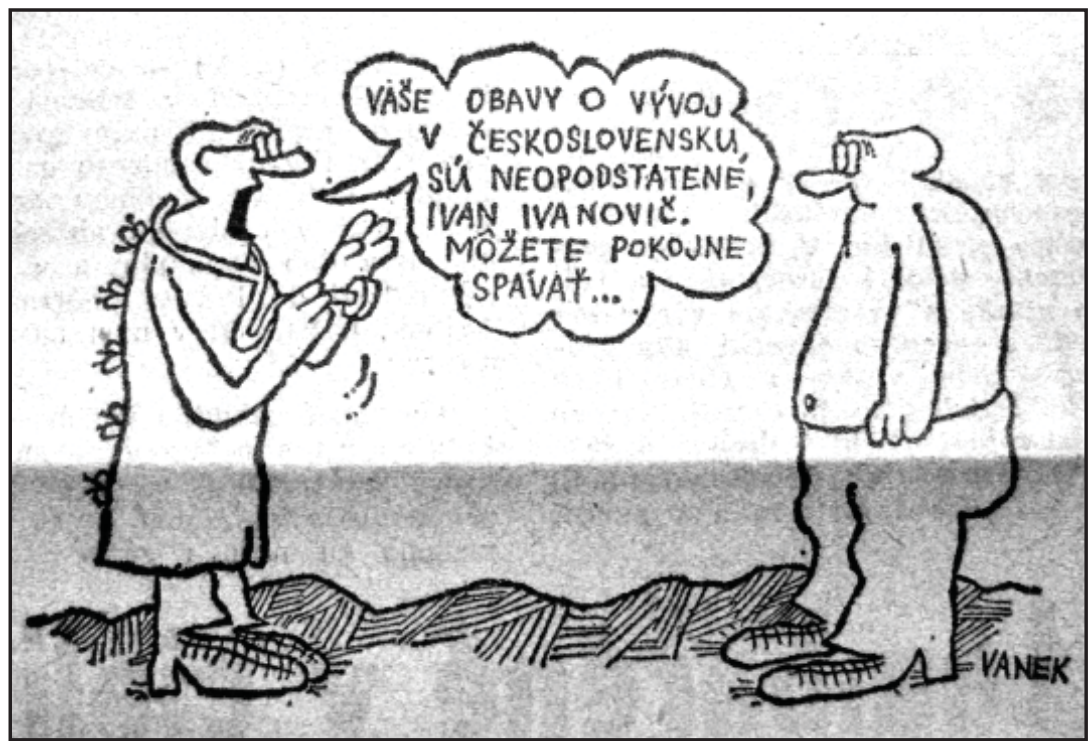

Figure 18: Marián Vanek, 16 July 1968, "Your fears about developments in Czechoslovakia are unfounded, Ivan Ivanovič. You can rest easily," Smena, 16 July 1968, (C) 2010 Marián Vanek / Artists Rights Society (ARS), New York / LITA, Slovak Republic. 
suggests Czechoslovakia was attempting to pull the reluctant Soviet Union down the path to reform. In the second cartoon, Marián Vanek pictures a gap between two sets of narrow- and wide-gauge rails. The man standing on the narrow (Czechoslovak) rails tells the Soviet soldier stroking his chin on the wider railway, "It doesn't depend on the width of the rails, but on where they lead" (figure 20). Like Kochan, Vanek depicts a physical separation between Czechoslovakia and the Soviet Union, which are not on the same track. Yet Vanek tries to strike a more reassuring note in suggesting the two countries share the same objective- democratic socialism - and thus the Soviet leaders should not be concerned if their Czechoslovak allies take a different route to reach this goal. As the cartoon figure says, the destination is more important than the path taken to reach it.

In addition to conveying fears of an invasion, some Slovak cartoons addressing the divisions within the Warsaw Pact also struck a more defiant tone. In a cartoon from mid-July, Vanek inscribes an outline of Czechoslovakia with the exhortation, "Hands off Czechoslovakia!!!" (figure 21). A Kochan cartoon published a month later depicts a man trying to psych himself up in front of a mirror: "Screw it, I am an anti-socialist element, I am an anti-socialist element, I am ..." (figure 22). Though Kochan's message is less blunt than Vanek's, it contains the same spirit of resistance to the Warsaw Pact's "friendly" bullying. If "the Five" refused to listen to reason and recognize that no threat of "anti-socialist elements" existed in Czechoslovakia, then the logical recourse for Slovaks and Czechs was to play the part their allies had written for them in the coming tragedy.

As seen in these cartoons, the Czechoslovak Spring appeared to come out of nowhere in 1968, catching many Slovak cartoonists by surprise. But while this development may have been unexpected, it was not unwelcome. Democratization brought Slovak cartoonists new opportunities, not only in terms of venues for publishing their creations, but also to practice their craft without political restraint. This newfound freedom initially surfaced in the critical manner in which Slovak cartoonists represented both public figures and also the anonymous representatives of an undemocratic regime. By giving a face to these formerly faceless functionaries and personalizing the country's problems, cartoonists called attention to the need for reform at all levels of the bureaucracy, while also reminding their audiences of the need to remain vigilant. Later, as the looming threat of an invasion cast doubt on democratization, they took the even more provocative step of painting their erstwhile allies in an unflattering light.

In turn, the concerns Slovak cartoonists expressed about democratization remaining cosmetic and superficial, little more than a wardrobe change, as well 


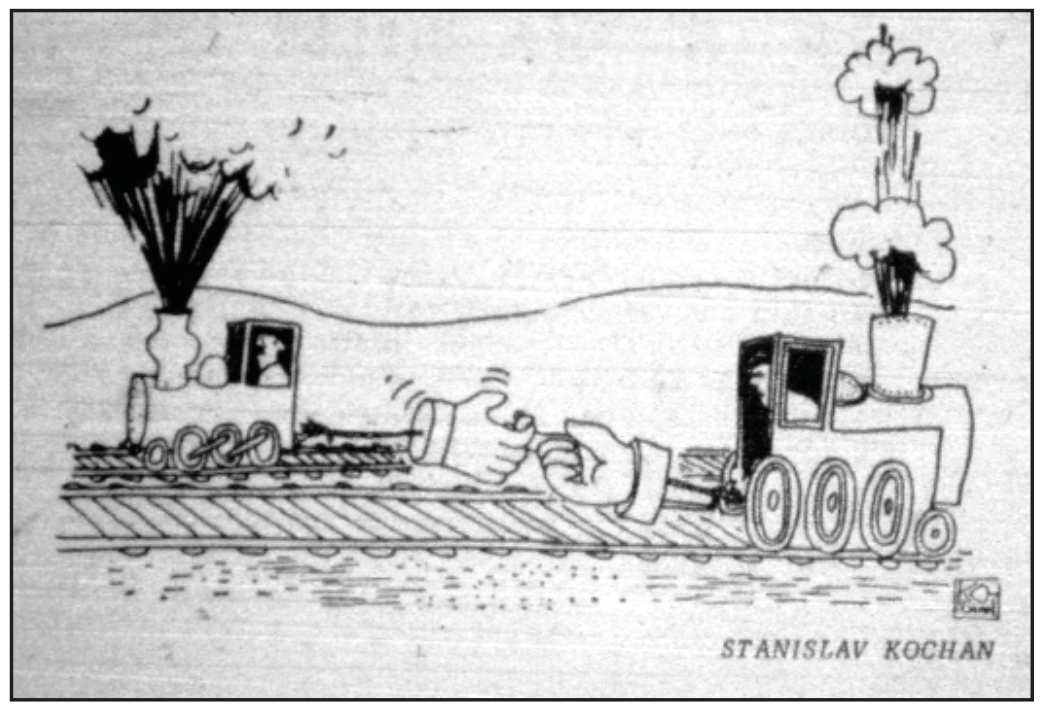

Figure 19: Stanislav Kochan, Kultúrny život, 2 August 1968, (C) 2010 Stanislav Kochan / Artists Rights Society (ARS), New York / LITA, Slovak Republic.

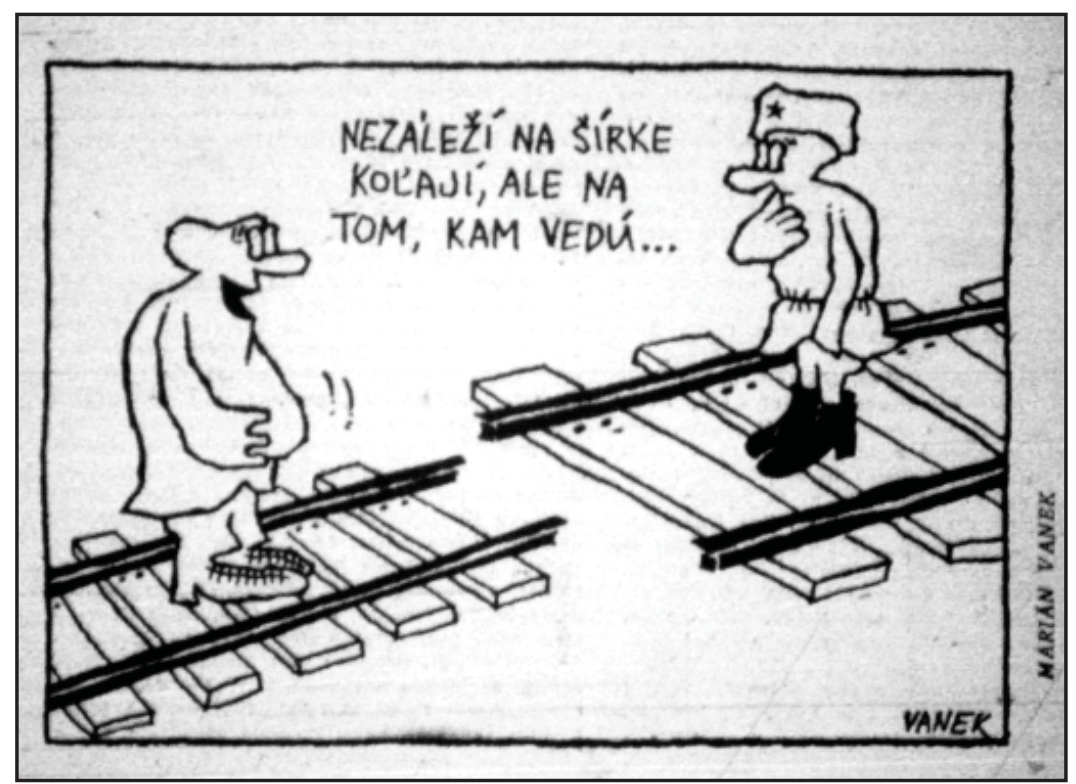

Figure 20: Marián Vanek, "It doesn't depend on the width of the rails, but on where they lead," Kultúrny život, 2 August 1968, (C) 2010 Marián Vanek / Artists Rights Society (ARS), New York / LITA, Slovak Republic. 


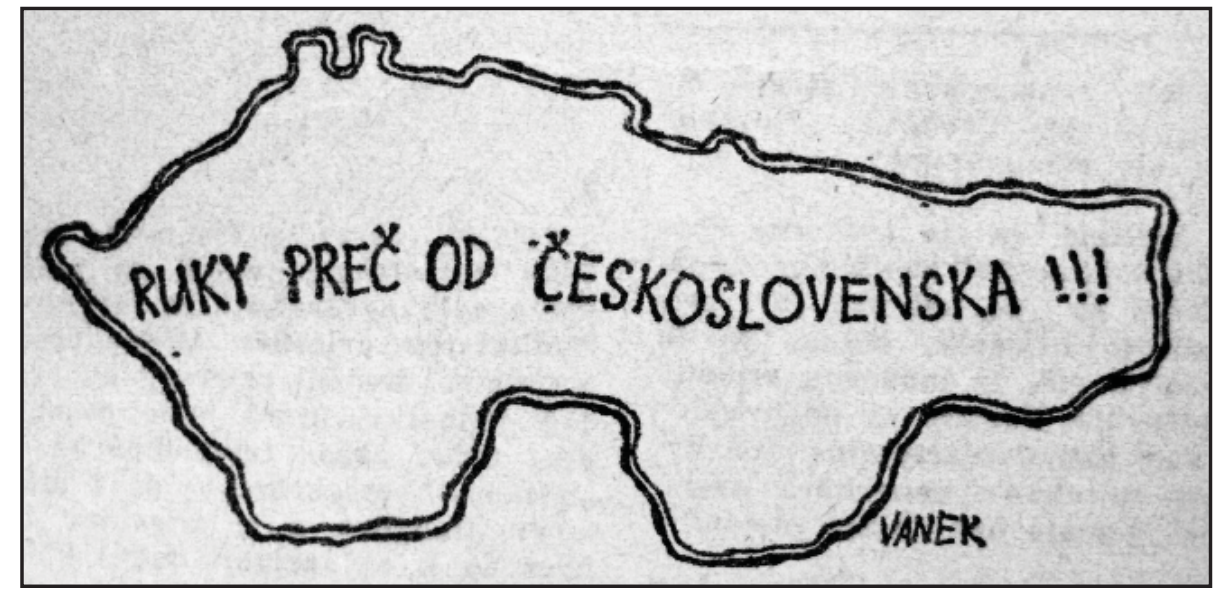

Figure 21: Marián Vanek, "Hands off Czechoslovakia!!!” Smena, 18 July 1968, (c) 2010 Marián Vanek / Artists Rights Society (ARS), New York / LITA, Slovak Republic.

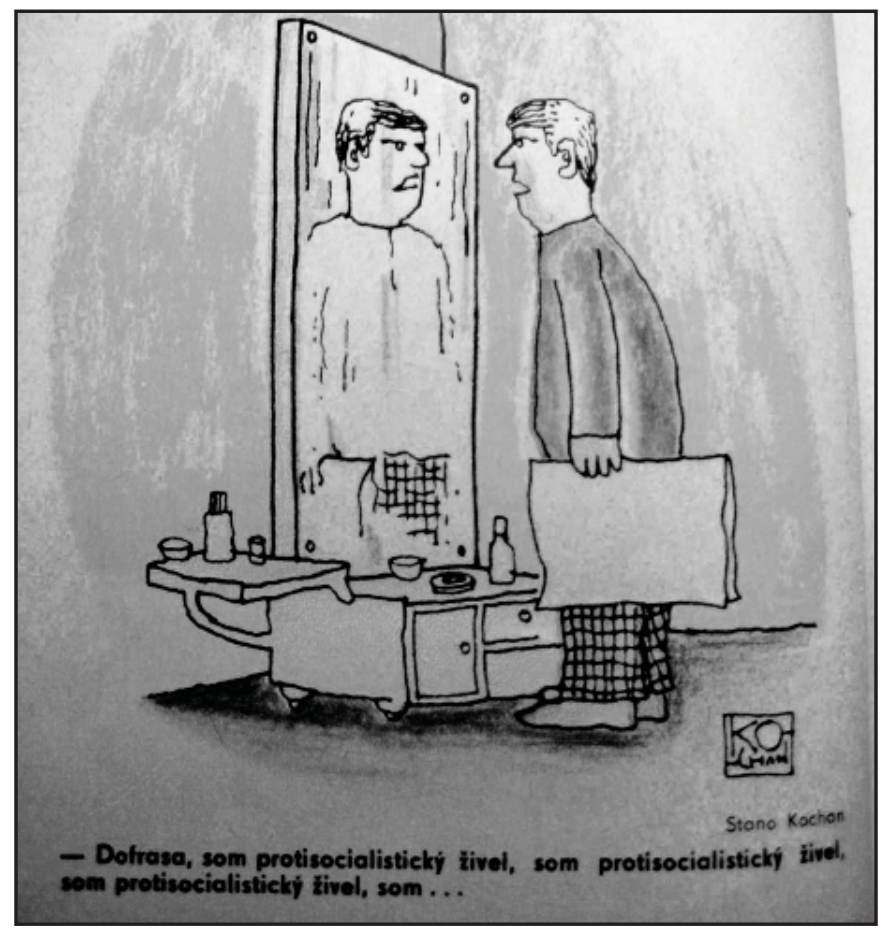

Figure 22: Stanislav Kochan, "Screw it, I am an anti-socialist element, I am an antisocialist element, I am an anti-socialist element, I am ..." Roháč, 14 August 1968, (c 2010 Stanislav Kochan / Artists Rights Society (ARS), New York / LITA, Slovak Republic. 
as their fears of a violent end to the Czechoslovak Spring, speak to their very real desire to see democracy realized. Contrary to the stereotype that Slovaks prioritized national interests over democratic reform during the Czechoslovak Spring, Slovak cartoons from the spring and summer of 1968 evinced a stronger interest in securing democracy for Czechoslovakia than in resolving the Slovak question. Indeed, by repeatedly invoking Slovakia's reputation as a democratic backwater, Slovak cartoonists issued a challenge to their audience: the achievement of thoroughgoing democratization within Slovakia should be a matter of national pride for Slovaks.

\section{“This National Question Is Damned Difficult,” Spring and Summer 1968}

Late in May 1968, shortly before the debate over federalization began to turn contentious, Marián Vanek published a cartoon in Smena that anticipated the problems to come in conjunction with the proposed Czechoslovak federation (figure 23 ). In the cartoon, two movers carry an oversized question mark. The second man laments the trouble their load causes them, complaining aloud, "This national question is damned heavy [t’ažká]." Vanek's clever pun-t'ažká means both "heavy" and "difficult"- hints at the problems that accompanied efforts to resolve the Slovak question during the Czechoslovak Spring. As Vanek suggests, the national question presented a weighty challenge for the reform movement, and it came to sow much of the distrust between Slovaks and Czechs that strained their relationship in the years to follow. Nonetheless, relatively few Slovak cartoons - and virtually no Czech cartoons - addressed explicitly national themes in the spring and summer of 1968. Democratization remained a more prominent and frequent subject of caricatures than federalization. When Slovak cartoonists addressed a federation and other Slovak national themes, they often did so in jest. Yet they also conveyed a belief more widely held among Slovaks that democratization needed to provide redress for their legitimate national grievances. As Slovak cartoons from this era reveal, much of the discord that cropped up from debates over the Slovak question in 1968 stemmed from disagreements over what exactly democratization entailed for Czechoslovakia's two titular nations.

Much of the rhetorical wrangling in 1968 reflected disagreements over the form of federalization and what priority to accord it in the context of democratization. At issue was not the idea of federation, which most Czechs were willing to concede as a necessary institutional expression of Czech-Slovak equality. Rather, the central point of contention was whether Czechoslovakia's titular nations could claim similar 


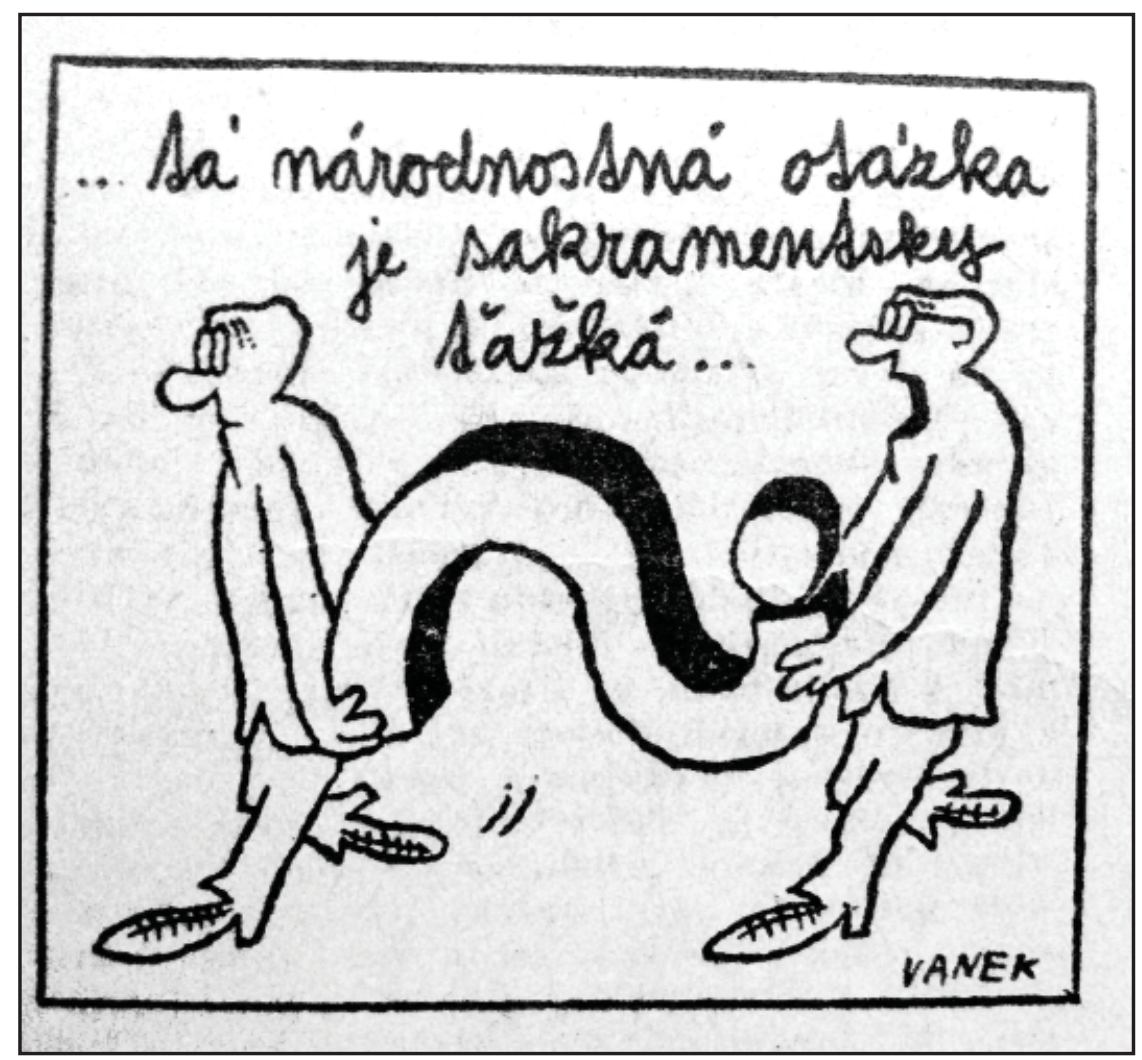

Figure 23: Marián Vanek, "This national question is damned heavy," Smena, 26 May 1968, C 2010 Marián Vanek / Artists Rights Society (ARS), New York / LITA, Slovak Republic. 
rights as individuals in a more democratic order. For Czechs, the individual citizen was the basic subject of democracy, meaning political representation and other considerations should be apportioned on a per capita basis. Yet Slovaks found this emphasis on the citizen problematic, since Czechs outnumbered Slovaks, and they sought a variety of safeguards - such as allocating equal numbers of parliamentary deputies to each nation, regardless of population - in order to prevent the "outvoting" (majorizácia) of the numerically smaller Slovak nation by the more populous Czech nation. But most Czechs found this position unacceptable, since it granted Slovaks outsized power. This core disagreement - whether and in what context the nation or the citizen was the more important subject of democracy-complicated efforts to strike a compromise on federalization that would satisfy members of both nations. Instead, the debate bred mutual suspicion as Czechs questioned Slovaks' commitment to democratization while Slovaks felt Czechs upheld a narrow view of democracy that shortchanged Slovaks' national rights. ${ }^{18}$

A symbolic yet significant Slovak complaint voiced publicly for the first time in 1968 concerned the way Czechoslovakia's coat of arms represented the Slovak nation. With the promulgation of a new constitution in 1960, the country adopted a new state emblem that many Slovaks regarded as an affront to their nation. Like the previous coat of arms, this new insignia reduced the emblem of the Slovak nation to a subordinate position as the shield on the breast of the two-tailed lion that represented the Czech nation. It also discarded the emblem used to represent the Slovak nation since 1848: a seal with a red backdrop that featured a white cross with two bars placed atop three blue peaks representing the mountain ranges Tatra, Mátra, and Fatra. ${ }^{19}$ In its place came a novel Slovak emblem. On a field of red stood a single blue peak representing Kriván̆ mountain, instead of the triple peaks, while the double-barred cross disappeared in favor of a gold flame symbolizing the Slovak National Uprising of $1944 .^{20}$

Though Kriván and the Uprising both had their place in Slovak national mythology, the Slovak emblem introduced in 1960 had offended many Slovaks because it disrespected a national tradition and suggested the Slovak nation was subservient to the Czech nation. Because Novotný was closely identified with the constitution of 1960 that brought the introduction of this new emblem, any criticism of it was tantamount to an attack on Novotný. Thus, it was only with Novotnýs ouster in 1968 that Slovaks had the opportunity to voice their dissatisfaction with this emblem. Moreover, calls for federalization during the Czechoslovak Spring provided a further impetus for a change in the Slovak and Czechoslovak emblems so that the Slovak nation would gain a more appropriate symbol. Many Slovaks came to 
see the emblem adopted in 1960 as an embodiment of their lack of equality and self-rule within Czechoslovakia. Consequently, in conjunction with federalization, several Slovaks urged a state emblem that would represent the national equality of the new federation, along with the adoption of a crest that would respect Slovak national traditions. When Slovaks addressed the issue of the coat of arms in 1968, they almost uniformly called for a return to the Slovak emblem used before $1960{ }^{21}$

In turn, the traditional Slovak emblem became the national symbol Slovak cartoonists in Roháč depicted most frequently during the Czechoslovak Spring to comment on the ongoing debates over Slovak national rights. In one caricature, Ladislav Čisárik spoofs the emblem of 1960 by depicting a man dressed like Jánošík, a Robin Hood-like figure from Slovak history, who runs up Kriváň intending to take an ax (another Slovak national symbol) to the flame on the mountain (figure 24). A similarly attired figure yells, "Stop, Jožo! You don't want to be around during the desecration of the state emblem." Similarly, an Ondrej Zimka cartoon published a few weeks later pictures a man carrying the double-barred cross up the three peaks from the original emblem in a cartoon titled, "Calvary of the Slov. emblem" (figure 25). Both cartoons suggest the restoration of the older Slovak emblem would require an uphill struggle, in no small part because the issue recalled the separatism of the wartime Slovak state, which used the traditional emblem as its official insignia. Defenders of the traditional emblem, like the Slovak heraldry expert Jozef Novák, stressed the historicity of the older Slovak emblem, locating its origins as a national symbol in the revolutionary year of 1848. Moreover, Novák noted this emblem had been used on the territory of Slovakia for centuries, and he argued this antiquity should override any connotations of the wartime state and its allegedly "clerico-fascist" tendencies. ${ }^{22}$

However, as the debate over the proposed federation grew heated in the summer of 1968, the traditional Slovak emblem remained an important symbol for Slovak cartoonists addressing national grievances. In July 1968, Mit'o Breza published a cartoon of a man carrying the cross past the triple peak while an unseen person lay in wait to club this restorer of the old emblem (figure 26). Similarly, a Milan Vavro caricature shows a Jánošík-esque figure crucified on the cross of the original shield with the explanatory caption, "This isn't how we imagine federalization" (figure 27). Vavro, like Zimka, invokes the theme of crucifixion to grab the attention of his audience and to impress upon his readers how the issue of emblems was of vital importance. Moreover, Breza and Vavro both suggest that Czechs are unwilling to work with Slovaks on resolving the national question, whether it concerns national and state emblems or the legal position of the Slovak nation within the Czecho- 


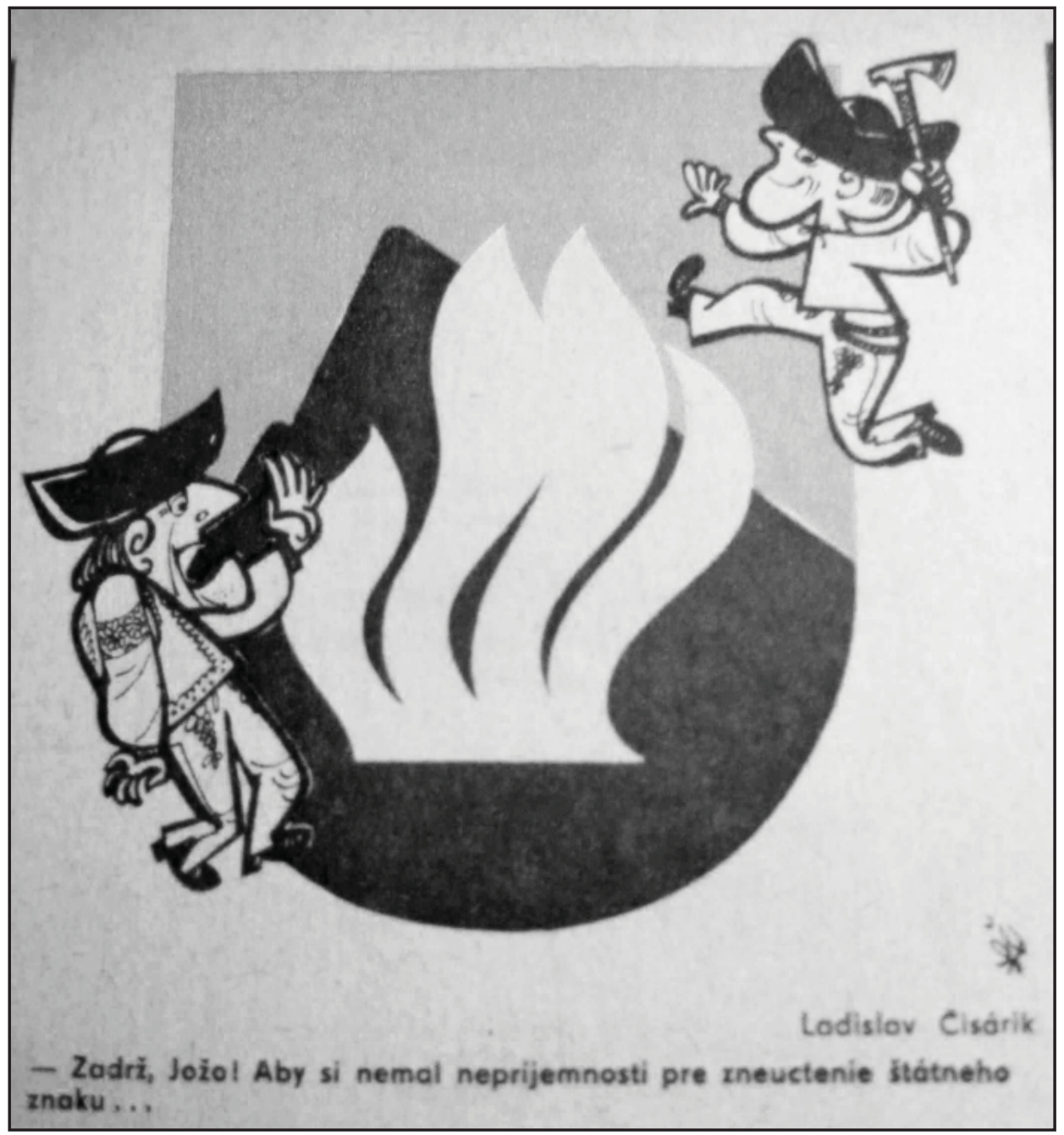

Figure 24: Ladislav Čisárik, "Stop, Jožo! You don’t want to be around during the desecration of the state emblem," Roháčc, 24 April 1968. 


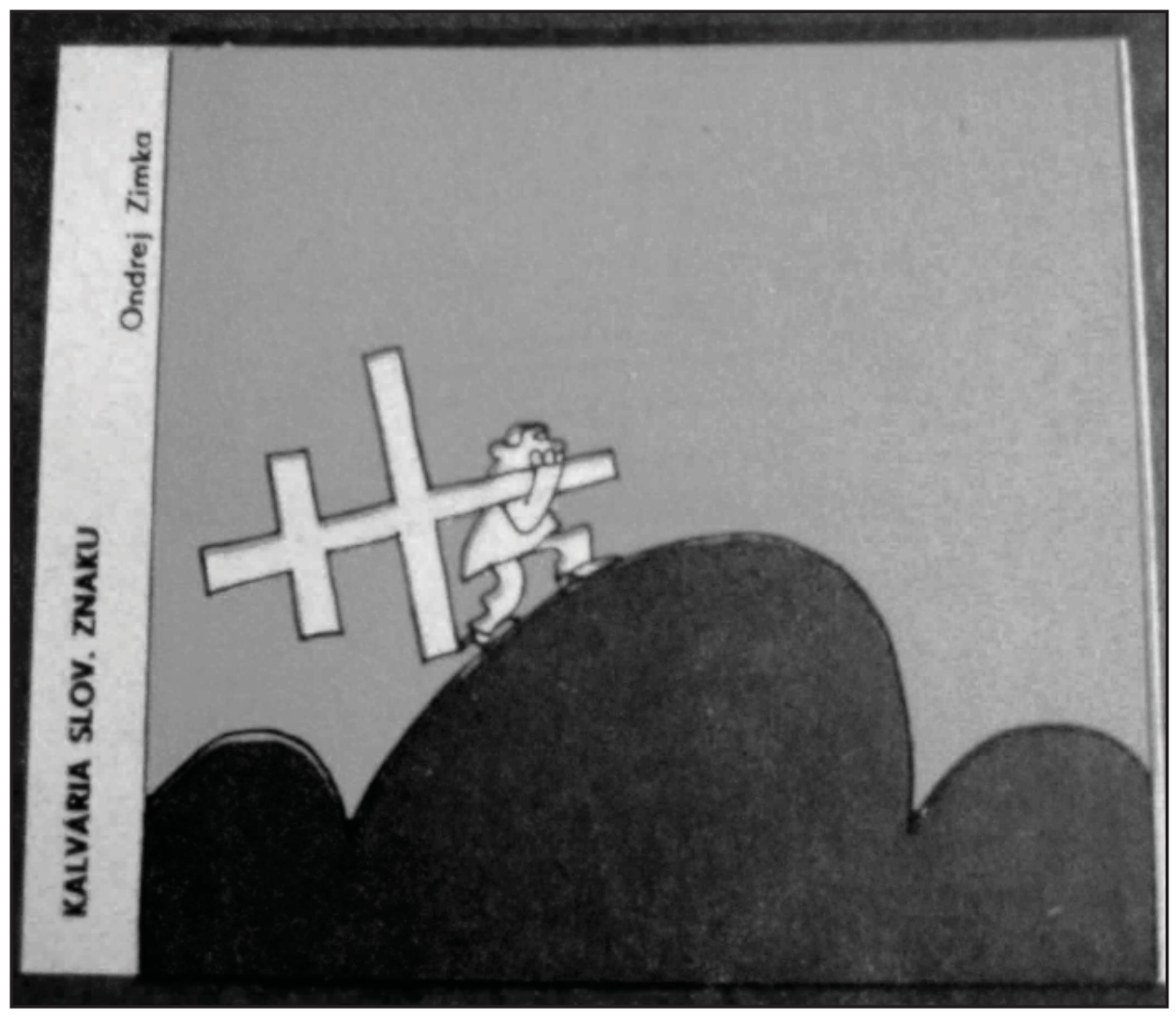

Figure 25: Ondrej Zimka, “Calvary of the Slov. emblem,” Roháč, 15 May 1968. 


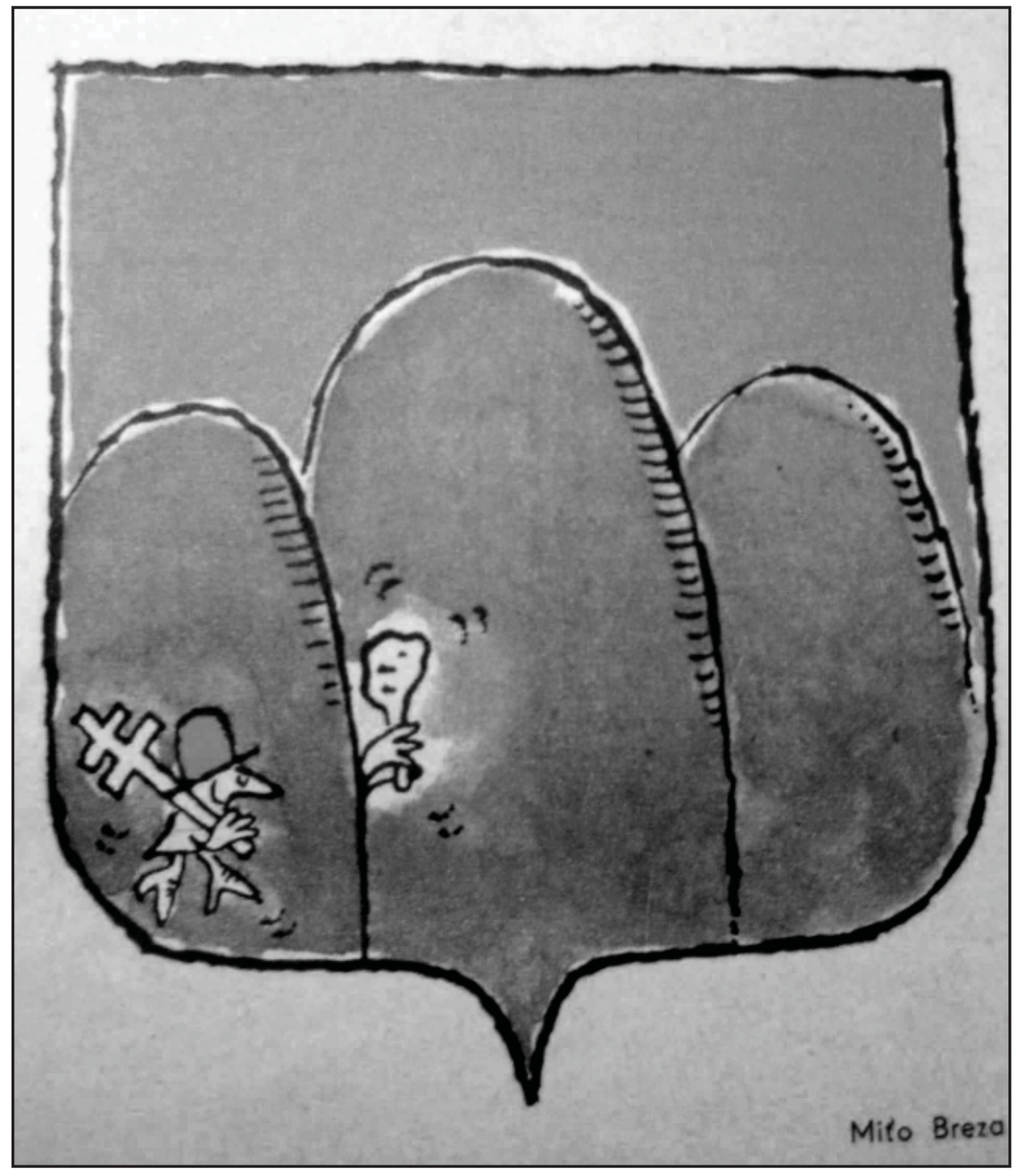

Figure 26: Mit'o Breza, Roháč, 24 July 1968. 


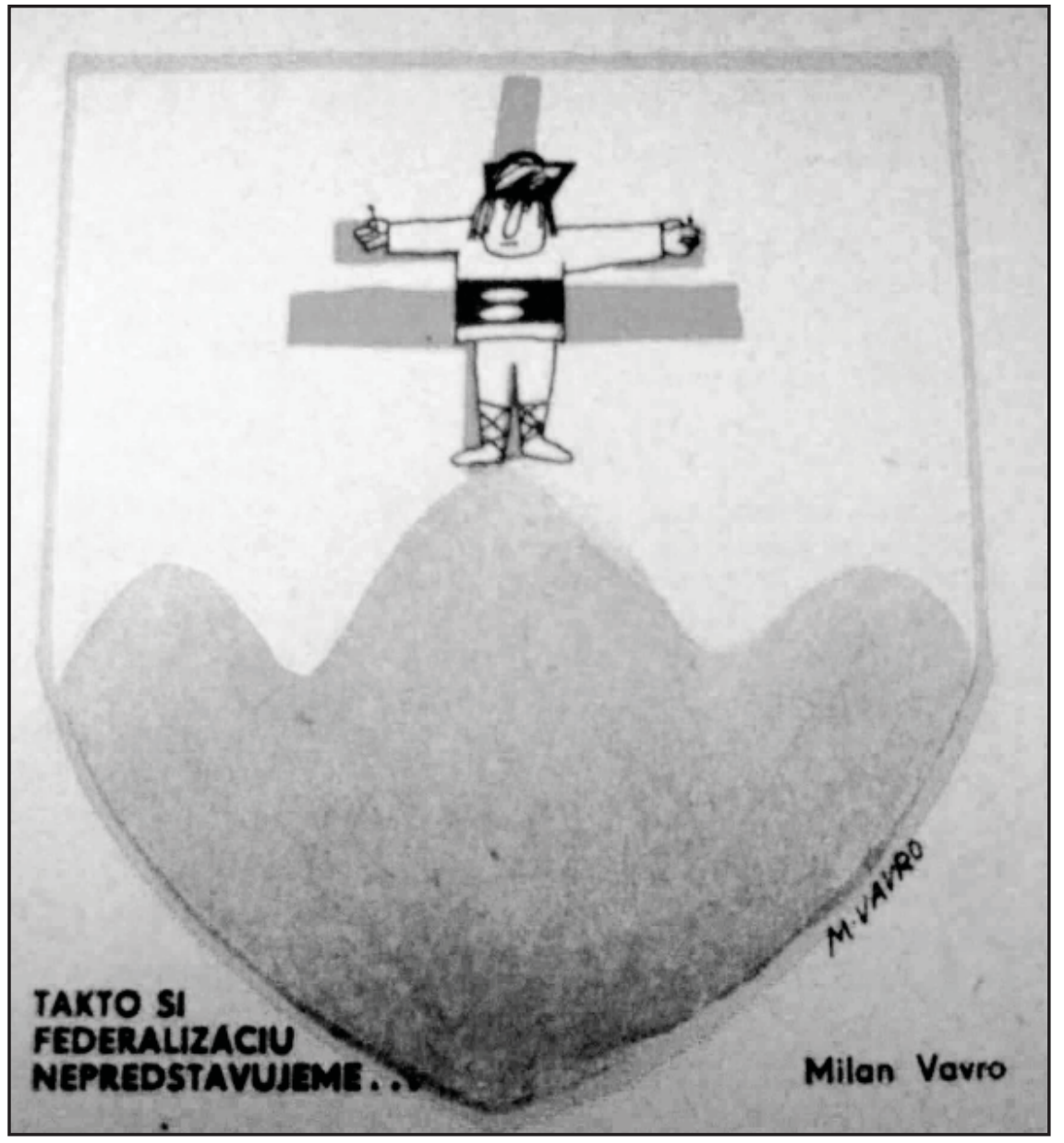

Figure 27: Milan Vavro, "This isn’t how we imagine federalization," Roháč, 31 July 1968 . 
slovak state. Furthermore, the recurrence of the Slovak emblem-one of the few explicitly national symbols to appear in Slovak cartoons during the Czechoslovak Spring-provides a clue to the importance of the emblem and federalization for Slovaks in 1968.

By the same token, the hubbub over the state emblem portrayed in Slovak cartoons attests to how cartoonists viewed such symbolic questions as symptomatic of deeper national issues that democratization needed to resolve. Shortly after the Slovak National Council issued a formal call for a federation in March 1968, Marián Vanek published a cartoon that represents Czechoslovakia with its Slovak and Czech halves stitched together with a string tagged "federation," picturing a federation as the thread that would sew up a festering wound and mend the country's national fabric (figure 28). Alternatively, Vanek's cartoon lends itself to the cynical interpretation that Slovaks and Czechs are not cut from the same cloth, meaning Czechoslovakia was a patchwork quilt with a federation the only thread that could hold it together. Nonetheless, Vanek and many other Slovaks saw a federation as placing the two nations on equal - and thus more democratic - footing by creating Czech national organs to parallel existing Slovak national organs, and by granting both nations considerable powers of self-rule. ${ }^{23}$

However, to many Slovaks, Czechs seemed not to share their commitment to democratizing the national arrangement of the Czechoslovak state, prompting several Slovak cartoonists to use caricatures to express their frustration with this perceived lack of Czech enthusiasm for federalization. In one cartoon, Viktor Kubal shows a young boy and girl painting a traditional Slovak emblem on a picket fence beside the graffito, "We want a federation!" (figure 29). A smiling onlooker prevents a furious policeman from stopping the child graffiti artists, reassuring the officer: "Let them be! It's lovely compared to what they could be writing." Kubal's cartoon suggests that those - the truncheon-wielding policeman appears to stand in for Czechs - who would try to silence Slovak expressions of national pride were overreacting. Calls for federalization, like other calls for Slovak national rights, were harmless in Kubal's view, particularly when Slovaks could be articulating far more dangerous demands for independence. In June 1968, Anton Hollý published a cartoon that conveys this sentiment even more explicitly. It shows a profederation demonstration marching past the Czech lion, which bears the warning, "Do not provoke!" (figure 30). As both Kubal and Hollý suggest, Czechs remained traumatized by the experience of the Second World War, when Slovakia grudgingly accepted its independence while the Czech Lands endured six years of German occupation. The slightest hint of 


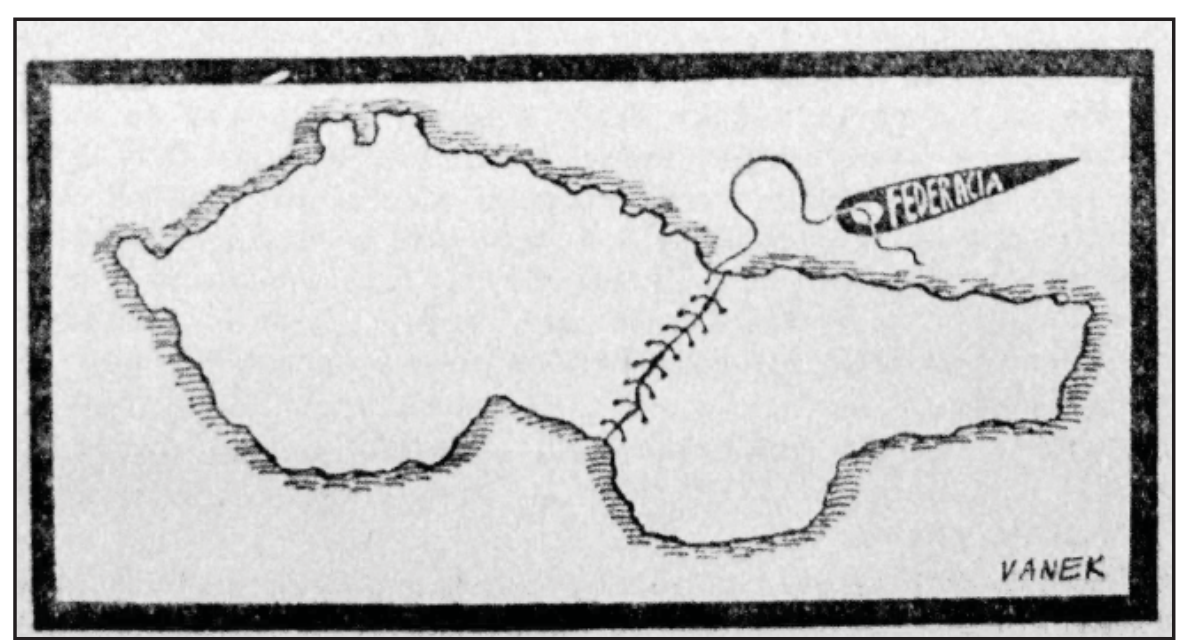

Figure 28: Marián Vanek, “Federation,” Smena, 27 March 1968, C 2010. Marián Vanek / Artists Rights Society (ARS), New York / LITA, Slovak Republic.

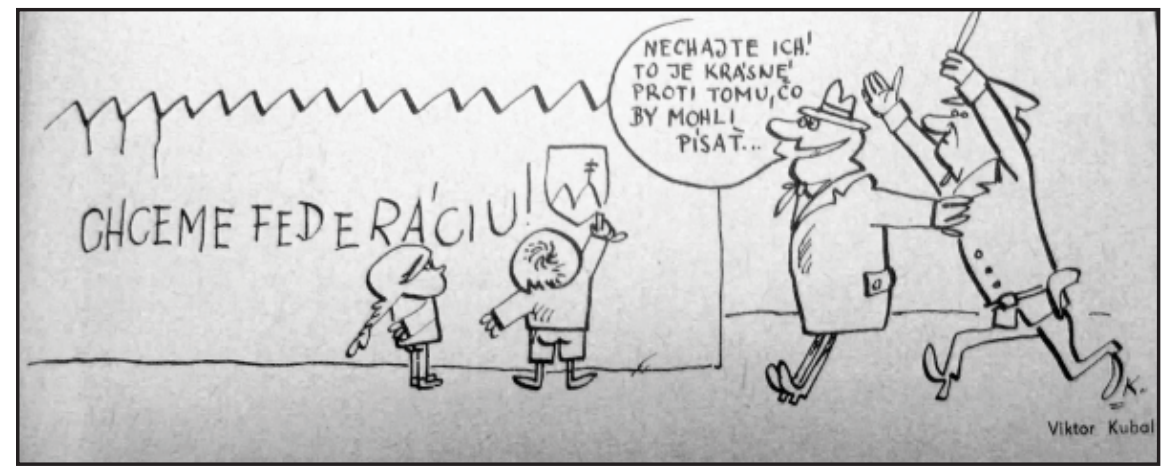

Figure 29: Viktor Kubal, “We want a federation!- - Let them be! It's lovely compared to what they could be writing," Roháč, 24 April 1968. 
Slovak self-rule, even within a common Czechoslovak state, prompted a visceral reaction from Czechs unwilling to humor Slovaks' legitimate national grievances.

In other cartoons, Kubal turned the tables of national egotism against $\mathrm{Czechs}$ to question their commitment to basic democratic precepts of equality and fairness. A cartoon from April 1968 pictures a large man attempting to wring every last drop of liquid out of a much smaller man before thinking better of it and remarking, "We'd better make a federation instead" (figure 31). Two months later, Kubal published a cartoon that uses a sliced cake to represent the "symmetrical model" (figure 32). To the left side (signifying the western, Czech half of the country) goes the entire dessert, save for a small wedge, indicating that Czechs would get the lion's share of the Czechoslovak cake if population, rather than national parity, were the decisive consideration in a democratic federation. In the cartoon's right panel (representing the eastern, Slovak half), Slovaks get but a single wedge of cake - along with a magnifying glass that makes their paltry portion look much larger than it actually is. In both cartoons, Kubal casts doubts on Czechs' willingness to play fair, even under a democratic order. The two cartoons suggest that national equality will remain illusory in Czechoslovakia until Czechs stopped trying to extract more than their fair share from Slovaks and instead went along with a more equitable distribution of their common property. ${ }^{24}$

Czechs' instinctive suspicion of demands for Slovak autonomy also left proreform Slovaks on the defensive about their devotion to democratization. As summer approached and the debate over federalization intensified, Czech reformers grew suspicious of a slogan popular among Slovaks: "First federalization, then democratization." This catchphrase suggested to Czechs that Slovaks' interest in democracy took a backseat to their national agenda. Yet the pithiness of this rallying cry was deceptive, since many Slovaks embraced this slogan because they regarded federalization as the democratization of Czechoslovakia's bi-national relationship and thus as a precondition for further democratic reforms. ${ }^{25}$ Still, Slovaks felt themselves under attack from Czechs for adopting this stance. Marián Vanek poignantly captured this sentiment in June 1968 with a cartoon that depicts a man holding a "federation" sign while wearing a gag labeled "democracy" (figure 33). Vanek's cartoon suggests democracy threatens to silence Slovaks' demands for a federation. But by the same token, the cartoon also carries the implication that pressure from Czech reformers to emphasize democratization cannot prevent Slovaks from making their case for a fairer solution to the Slovak question.

Conversely, Slovak cartoonists also appealed to other Slovaks not to allow their desire for federalization to sidetrack the more important issue of democratization. 


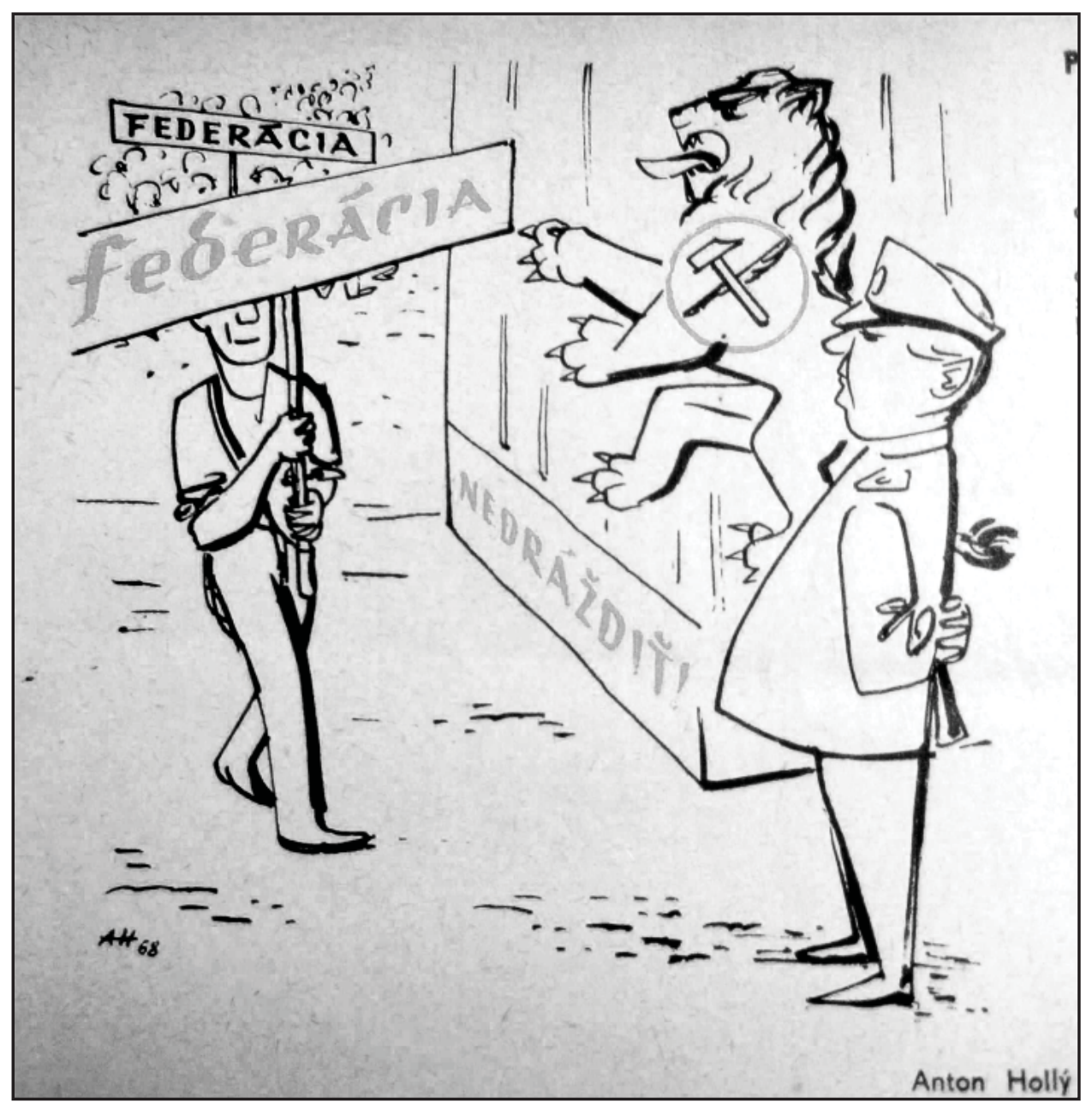

Figure 30: Anton Hollý, “Do not provoke!” Roháč, 12 June 1968. 


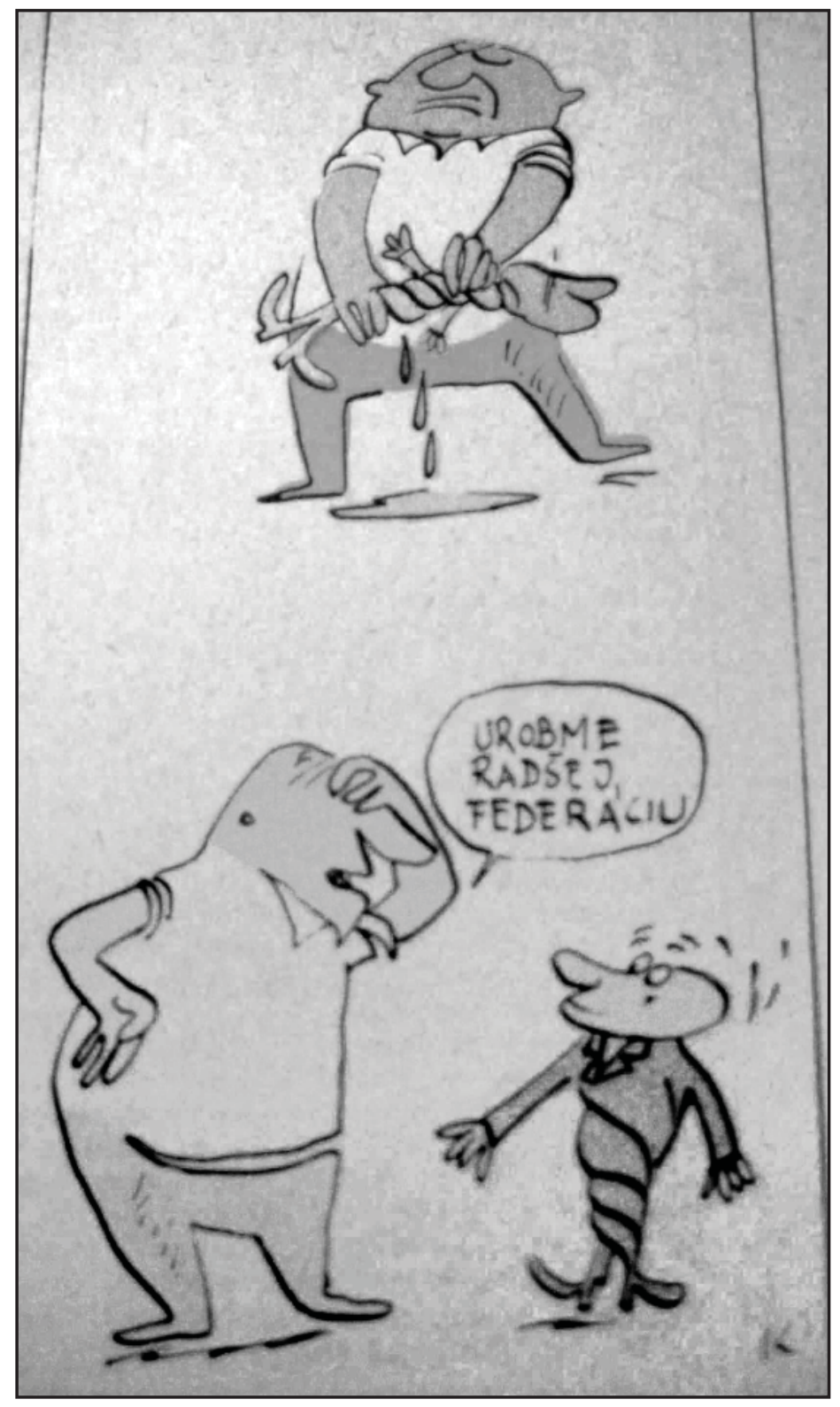

Figure 31: Viktor Kubal, "We'd better make a federation instead," Roháč, 17 April 1968. 


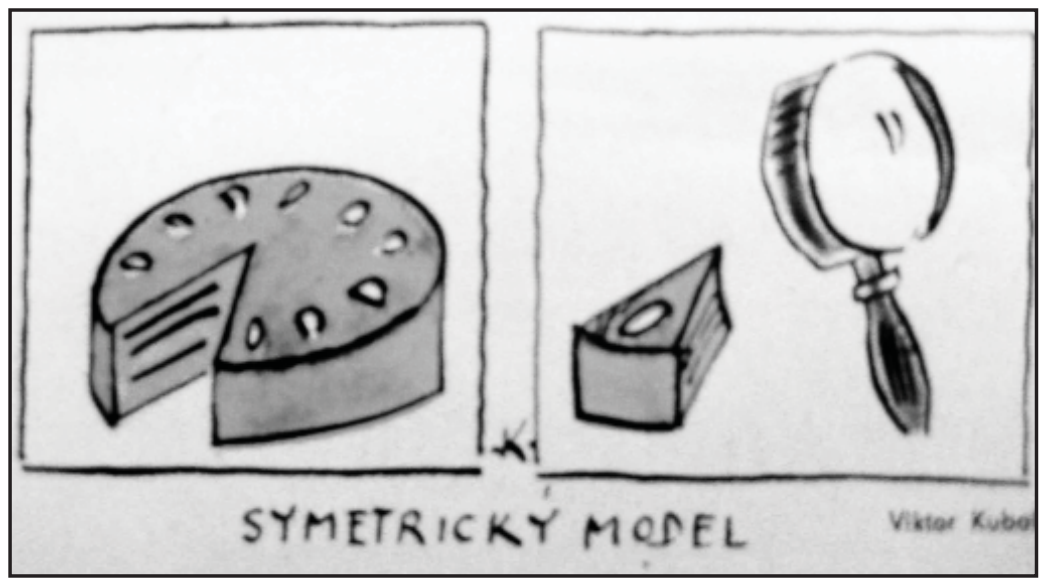

Figure 32: Viktor Kubal, “The symmetrical model,” Roháč, 12 June 1968.

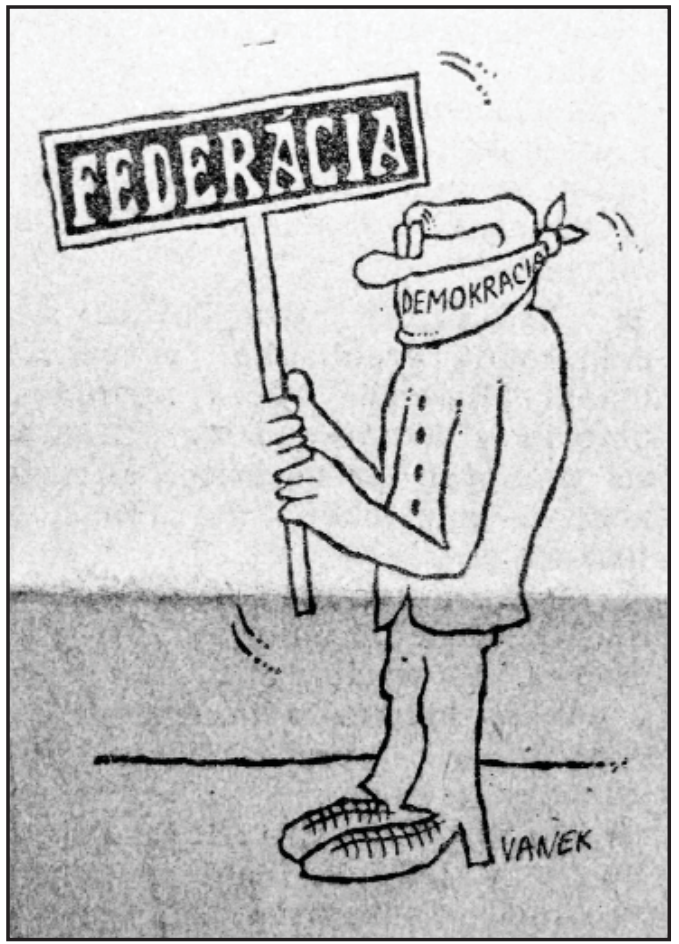

Figure 33: Marián Vanek, Smena, 19 June 1968, (C) 2010 Marián Vanek / Artists Rights Society (ARS), New York / LITA, Slovak Republic. 
When the polemics of the federalization debate reached their most acrimonious levels just as pressure from "the Five" mounted in early July, Vanek sought to remind his audience that Slovaks and Czechs shared overarching interests. In a cartoon printed in Kultúrny život, Vanek pictures a deserted island where two men sit with their backs to each other. One of them holds a sign that says "federation" (figure 34). The cartoon lends itself to multiple interpretations. In one reading, some Slovaks would take their demands for federation to absurd extremes, while an alternative implication was that some Czechs would ignore legitimate Slovak grievances. In either case, the failure to find common ground on federalization was creating divisions between Slovaks and Czechs at a time when Czechoslovakia found itself increasingly isolated from its Communist allies. In order to avoid such undesirable internal tensions, Vanek urges Slovaks to make common cause with Czechs on the more urgent issue of preserving democratization, even if it meant putting federalization on the back burner for the moment.

At the height of the federalization debate, Stano Kochan created a cartoon that provided perhaps the best symbol of the frustrations mounting among both Slovaks and Czechs over their inability to agree on the relationship between federalization and democratization. Kochan published a cartoon in Roháč with a caricature of Dubček leaning on a sword and looking over a tangle of rope labeled "the Czechoslovak knot" (figure 35). More provocative is the caption: "A great opportunity to become Alexander the Great." Kochan's Gordian knot seems to represent the Slovak question and its indecipherable complexities, leading him to wonder whether Dubček should cut the cord, since only such a bold stroke could solve the intractable problem the Slovak question posed at the moment. But while the "Alexandrian solution"- cutting the Gordian knot - might suggest the severing of state ties between Slovaks and Czechs, Kochan only offers such a solution as a joke. In turn, his use of humor allows the cartoon to capture the exasperation felt by both Slovak and Czech participants in the federalization debate. No one from either nation openly advocated the disintegration of Czechoslovakia, nor would such a proposal have found public support during the Czechoslovak Spring. Nonetheless, on some level both Slovaks and Czechs would have been relieved to have a decisive resolution of the Slovak question one way or the other, particularly after the weeks and months of wrangling and bickering over the form of the coming federation. ${ }^{26}$

The tricky issue Slovak and Czech reformers struggled to resolve in the spring and summer of 1968 was reaching an agreement on how democratization and federalization fit together. In August 1968, Milan Stano published a cartoon suggesting two different meanings that encapsulated the frustrations felt on both 


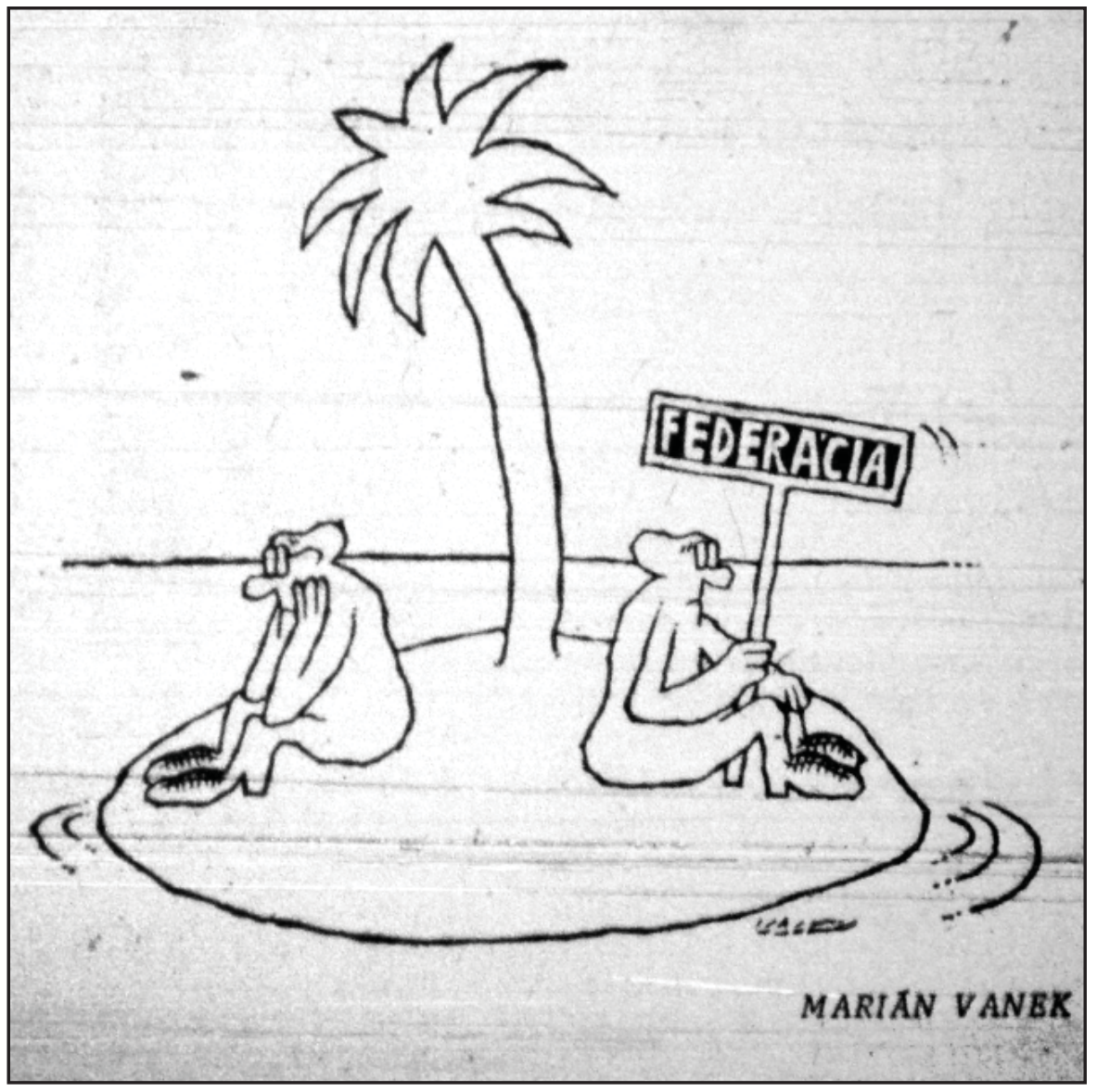

Figure 34: Marián Vanek, "Federation," Kultúrny život, 5 July 1968, (C 2010 Marián Vanek / Artists Rights Society (ARS), New York / LITA, Slovak Republic. 
sides (figure 36). The cartoon, which appeared in Pravda, portrays a Slovak man in $k r o j$, the traditional folk costume, looking puzzled. As he scratches his head over a "do-it-yourself" (urob si sám) book, the humble Slovak fumbles with building blocks labeled "Slovakia," "Democracy," and "Federation." The juxtaposition of the blocks is suggestive: between "Slovakia" and "Democracy" sits "Federation." In a more literal interpretation, the cartoon appears to show federation standing in the way of democracy for Slovakia, reflecting the sentiment of many Czechs growing impatient with Slovaks' insistence on federalization before democratization. Yet Stano's cartoon, like Kochan's rendering of the Slovak question as a Gordian knot, also captures the sheer complexity of the issues at stake during the Czechoslovak Spring. The bewilderment of the simple Slovak pondering the daunting task before him captures the difficulty of the task facing other Slovaks like him. It is obvious that Slovakia, democracy, and federation all go together, yet it remains unclear both to this ordinary Slovak and to the cartoon's Slovak audience how these building blocks should be assembled to construct a democratic, federative Czechoslovakia.

\section{The Aftermath of the Invasion, Late Summer and Autumn 1968}

As it happened, Slovaks never got a chance to solve their democratic conundrum. The Warsaw Pact invasion of Czechoslovakia of 20-21 August threw a monkey wrench into democratization, which also complicated efforts at federalization. At the same time, the shared tragedy of the invasion temporarily smoothed over the national differences that had strained relations between Slovaks and Czechs. A Viktor Kubal cartoon from mid-September shows a Slovak, Czech (Bohemian), Magyar, Gypsy (Roma), and Moravian as "the most loyal friends of recent days," walking arm-inarm and united by their common Czechoslovak patriotism, which has trumped their separate national affinities in the face of the shared tragedy (figure 37). The prospects for democratization looked bleak in the wake of the invasion, as Marián Vanek observes in a cartoon printed in what proved the last issue of Kultúrny život. In the caricature, a functionary stands at a dais with a gun barrel at his back as he shouts, "Comrades! We must stop with this democracy!" (figure 38). As Vanek's cartoon indicates, external forces might try to kill off democratization in Czechoslovakia, but Slovak cartoonists refused to go down without a fight.

Initially, Slovak cartoonists held out hope that at least some of the gains of the Czechoslovak Spring would survive the invasion and occupation. In a cartoon from early September, Dušan Junek suggests the builders of democracy had left 


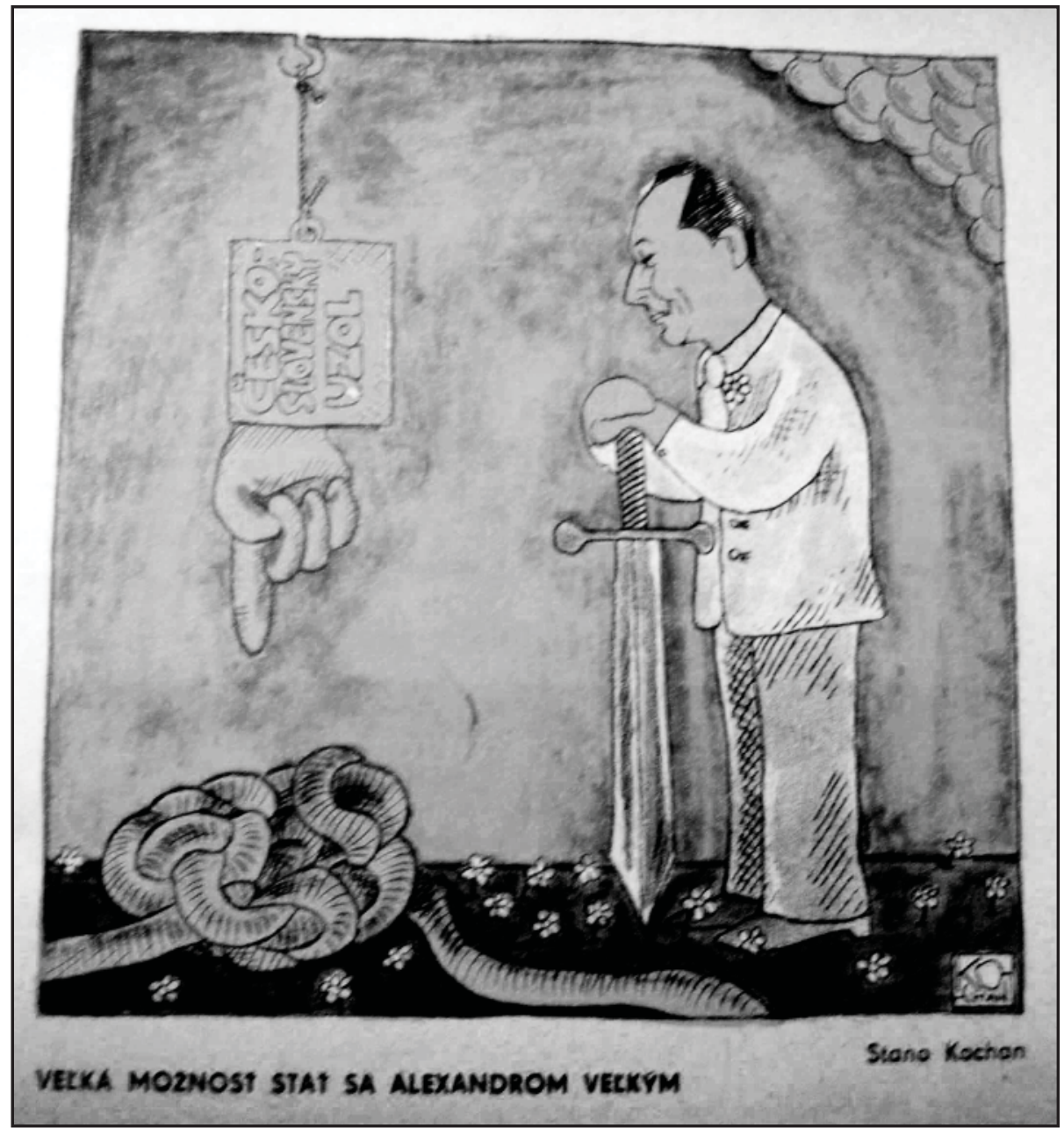

Figure 35: Stanislav Kochan, "A great opportunity to become Alexander the Great," Roháč, 10 July 1968, (C) 2010 Stanislav Kochan / Artists Rights Society (ARS), New York / LITA, Slovak Republic. 


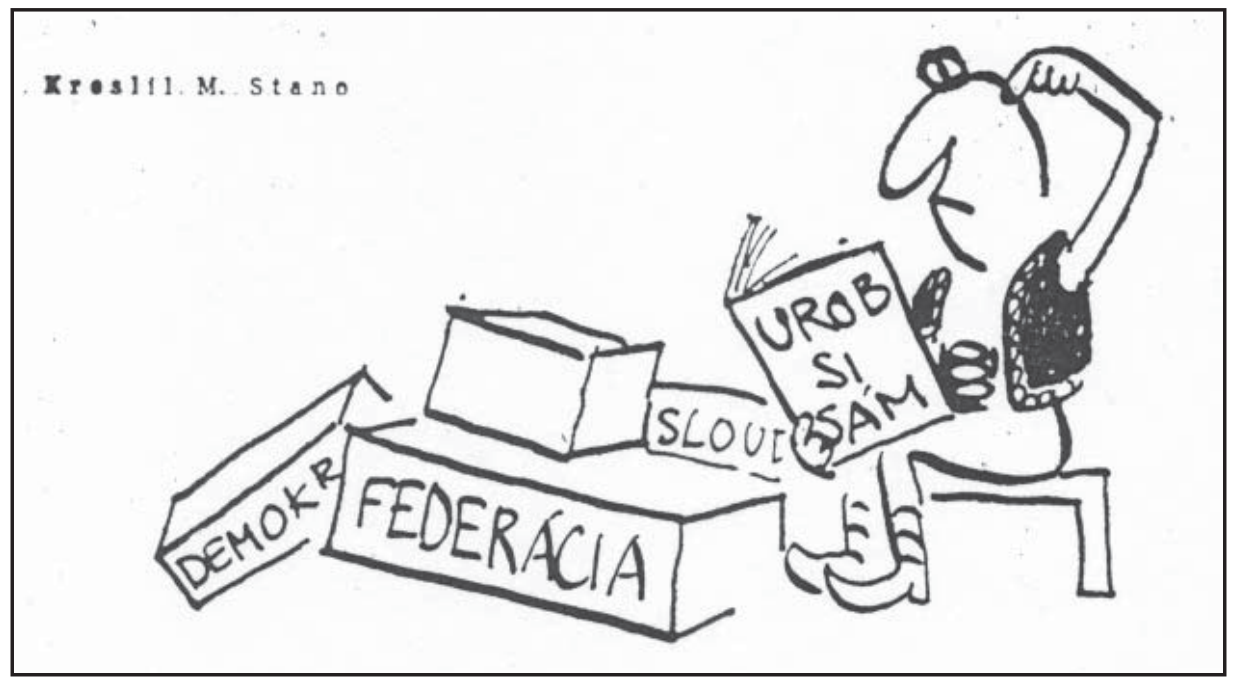

Figure 36: Milan Stano, "Do-it-yourself: Democracy, Federation, Slovakia," Pravda, 9 August 1968.

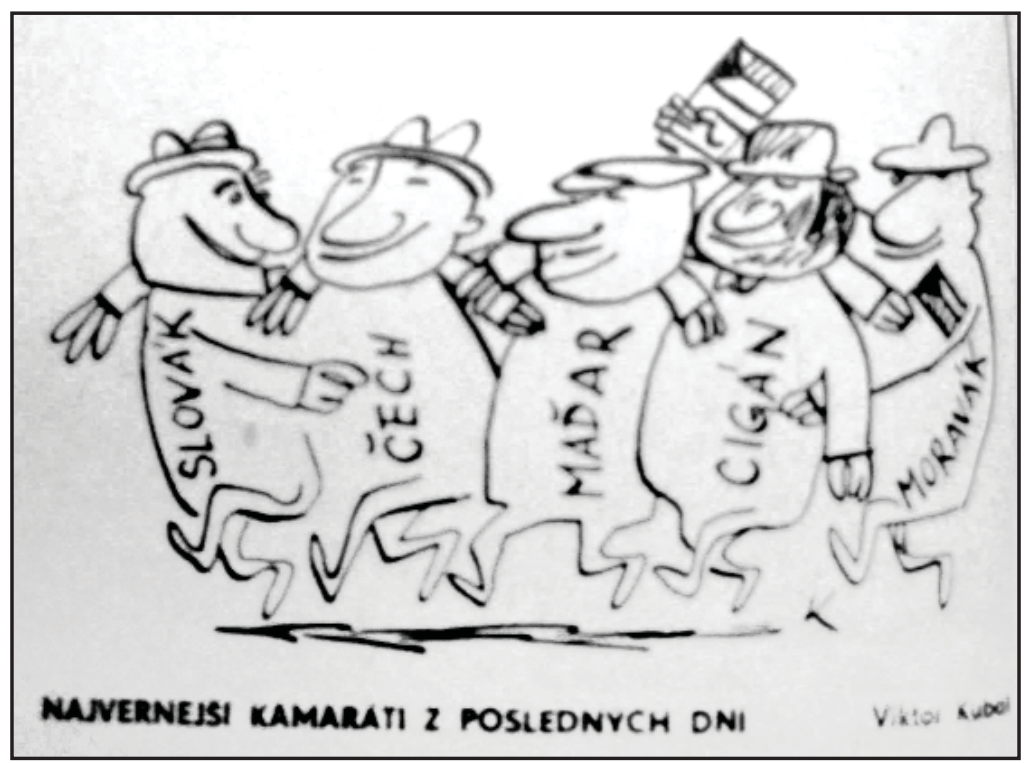

Figure 37: Viktor Kubal, "The most loyal friends of recent days: Slovak, Czech, Magyar, Gypsy, Moravian,” Roháč, 18 September 1968. 


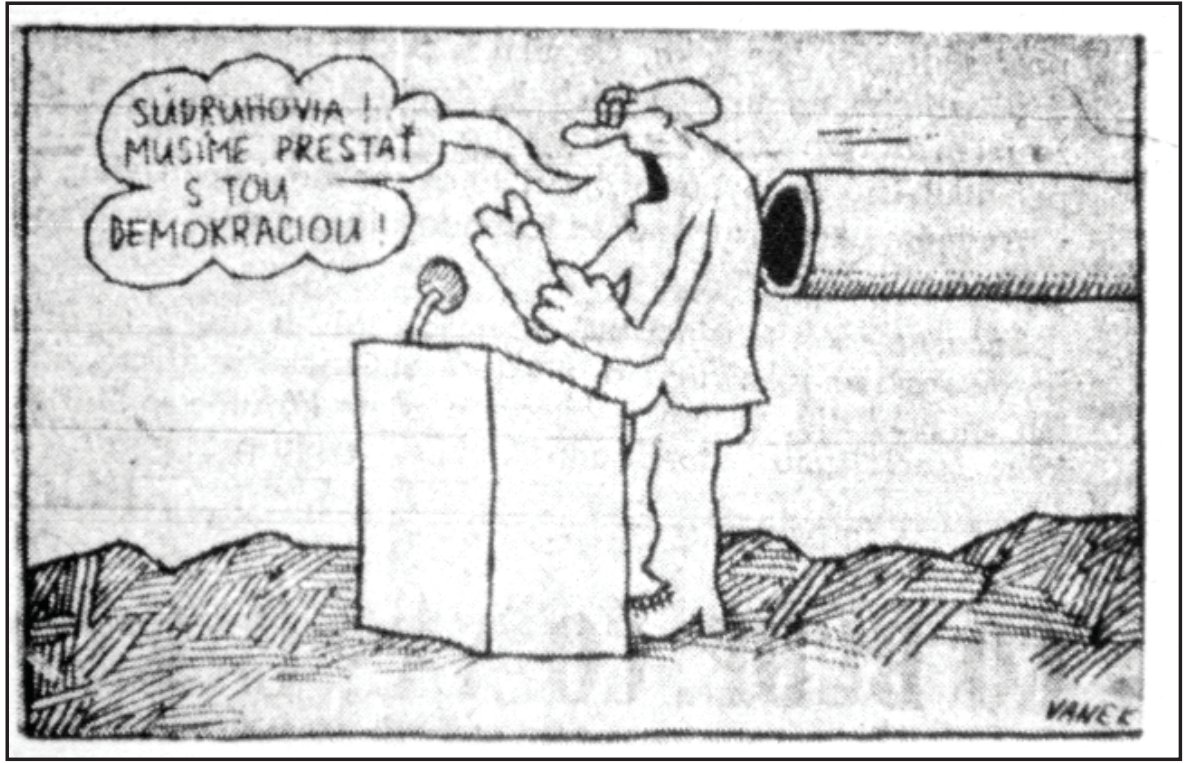

Figure 38: Marián Vanek, "Comrades! We must stop with this democracy!” Kultúrny život, 27 August 1968, (C) 2010 Marián Vanek / Artists Rights Society (ARS), New York / LITA, Slovak Republic.

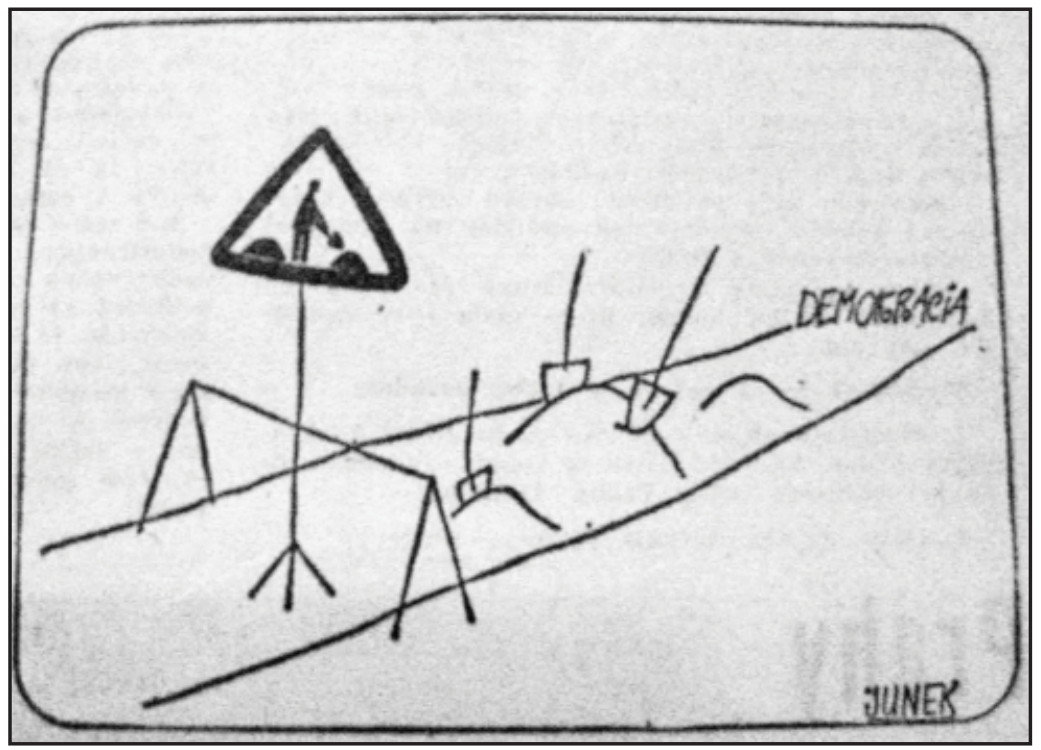

Figure 39: Dušan Junek, “Democracy,” Smena, 6 September 1968. 
the job half-completed, or that democracy had simply taken a detour (figure 39). It pictures a road under construction behind a barricade, with "democracy" standing in the distance. All Czechoslovakia needed, Junek implies, was to get back to work so the country could overcome these bumps in the road and reach democracy at last.

Yet Slovak cartoonists most vividly expressed the mix of longing and dismay they felt in the humorous slant they tried to put on a depressing situation. When Rohác resumed publication in mid-September, following an unplanned four-week break due to the invasion, the editor, Anton Hollý, addressed the issue of satire in a letter to the magazine's readers. Noting how the Warsaw Pact commanders had claimed a military withdrawal from Czechoslovakia was contingent on "the normalization of economic, political, social and cultural conditions," Hollý offered his belief that "a satirical magazine has its own place" in the realm of culture. "We think [Rohác] should continue to publish under normalization as well." ${ }^{27}$ In this spirit, a Vanek caricature renders "socialism" as a patient with a bandaged head receiving the grim prognosis from a doctor: "Well, it looks to me like you're going to lose your human face" (Figure 40). The cartoon skewers the de facto slogan of the Czechoslovak Spring - "socialism with a human face"-in order to suggest how socialism had lost (human) face as a consequence of the Warsaw Pact invasion. Vanek's cartoon conveys his determination and defiance, as well as a certain sense of resignation at the likelihood that democratization had met a definitive end in Czechoslovakia.

Much of the humor that appeared in cartoons from the autumn of 1968 took a similarly macabre tone. For instance, in October, Vanek published a caricature that shows a cartoonist on a scaffold with his head in a noose, offering a last-minute confession before his hanging: ". . . and then I began to publish my political cartoons in Smena" (figure 41). Though Vanek draws his doomed cartoonist with the same generic features he used in all his caricatures from the Czechoslovak Spring, the placement of his signature on the coat of the condemned man, along with the cartoon's publication in Smena, strongly hints that Vanek is, in fact, caricaturing himself. The gallows humor allows him to make a haunting prediction about the punishment he could expect for the dozens of political cartoons he had published in Smena, including this one. Likewise, Vanek foretold the demise of Slovak satire in another cartoon, also published in Smena, which shows a man reading an issue of Roháč (figure 42). On the cover, a fingertip appears poised to squash the namesake stag beetle, whose limbs are already in bandages, and the description of the magazine on the masthead is altered to read "humorous satirieat weekly," suggesting unseen forces-Vanek does not show the face of the finger's owner-were preparing to crush satire. The onset of "normalization" after the invasion threatened the return of strict 


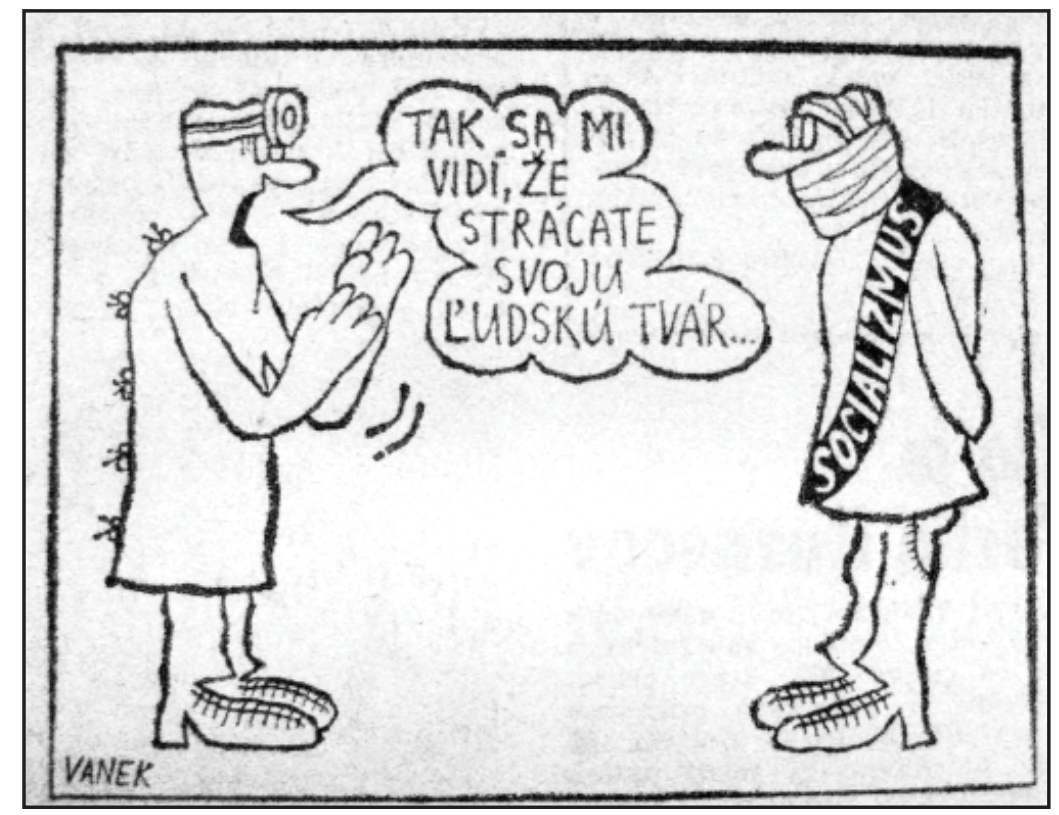

Figure 40: "Well, it looks to me like you're going to lose your human face," Smena, 10 September 1968, (C 2010 Marián Vanek / Artists Rights Society (ARS), New York / LITA, Slovak Republic.

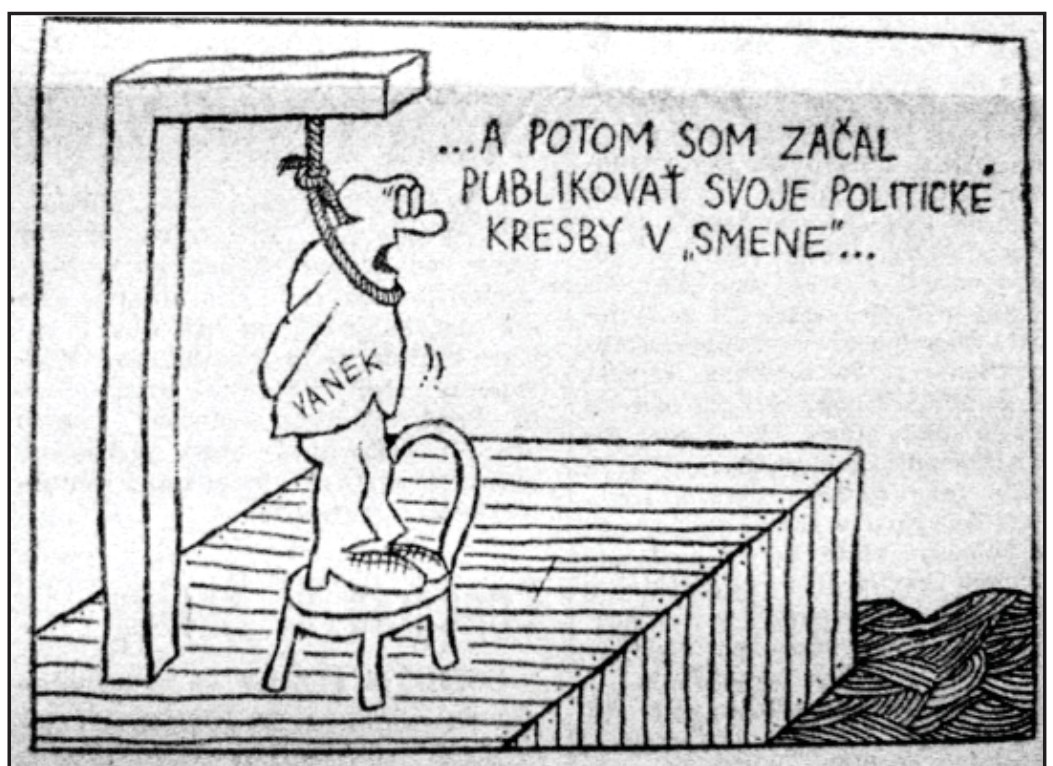

Figure 41: Marián Vanek, “... and then I began to publish my political cartoons in Smena," Smena, 9 October 1968, (C) 2010 Marián Vanek / Artists Rights Society (ARS), New York / LITA, Slovak Republic. 


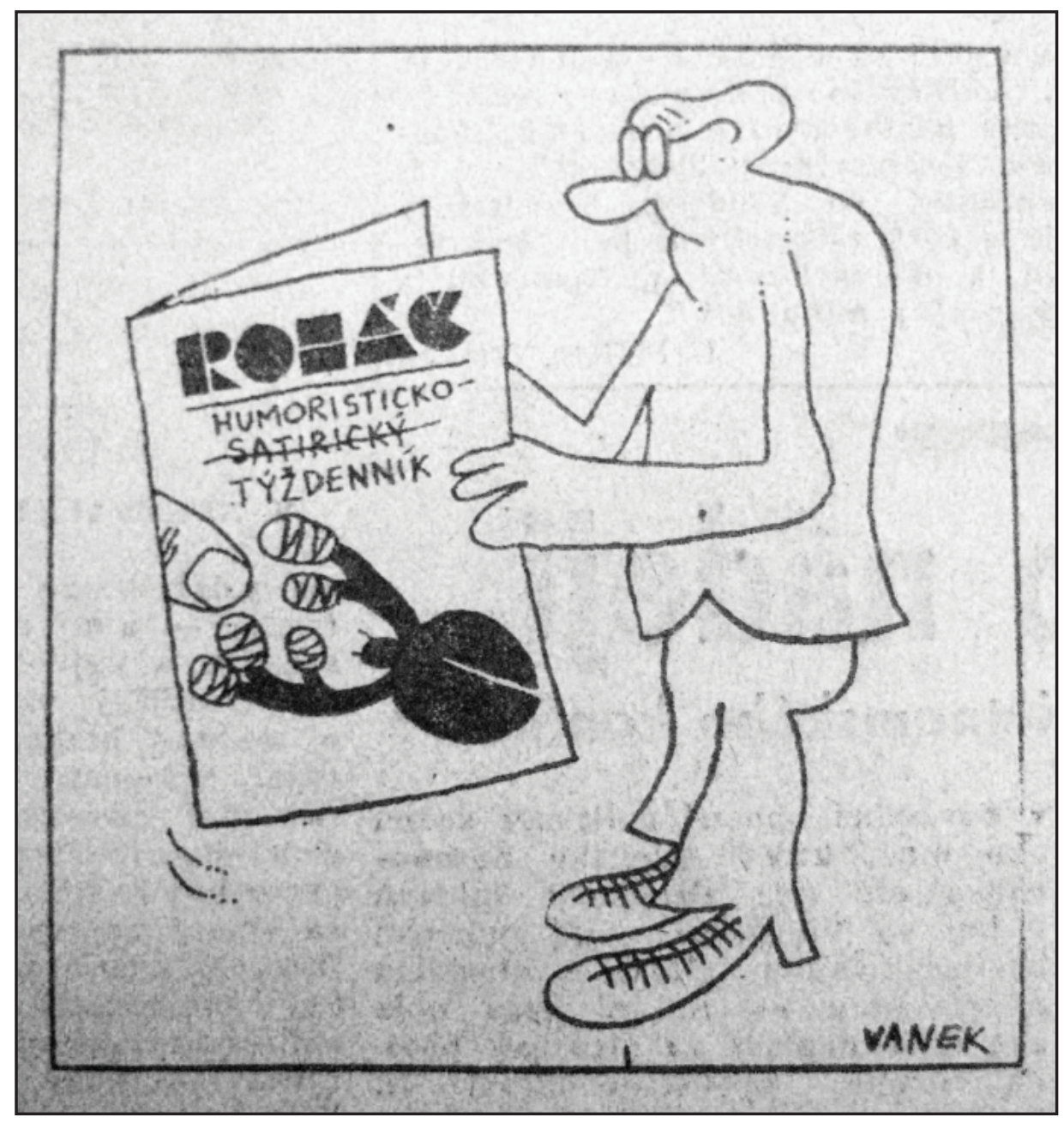

Figure 42: Marián Vanek, “Roháč: A Humorous satirieal Weekly,” Smena, 24 October 1968, (C) 2010 Marián Vanek / Artists Rights Society (ARS), New York / LITA, Slovak Republic. 
political controls on cartoonists in an effort to eliminate the subversive power of satire. In the process, the occupation authorities would strike the satire right out of Roháč. These cartoons from the months immediately after the invasion show Vanek and other cartoonists trying to enjoy a final hurrah while they still had the freedom to caricature whatever they wanted. The resort to black humor was also subversive, since cartoonists were using satire to announce the end of satire.

Not even federalization - an almost sacred cause for many Slovaks during the Czechoslovak Spring - was off limits to the incisive wit of Slovak cartoonists. While democratization, like most of the reform movement, met a premature demise, federalization proceeded under trying circumstances after the Warsaw Pact invasion. When the National Assembly passed the law on federation on 28 October 1968, the fiftieth anniversary of Czechoslovak statehood, Junek mocked the Slovak nationalists who regarded this achievement as a great triumph (figure 43). In a cartoon printed in Smena, he portrays a man rejoicing to a crowd of Slovaks: "Brothers! The time has finally come when we only have ourselves to blame for mistakes!" As if the cartoon's message - Slovaks should be careful about what they wished - was not obvious, Junek underscores this point with the national symbols that appear in the crowd: the traditional Slovak crest and the flag used as the standard of the wartime, Nazi-aligned Slovak state. Junek's caricature thus offers a warning to Slovaks to keep their national yearnings in check. The birth of the federation in such difficult and undemocratic conditions threatened to exacerbate the national fissures that seemed to emerge during the federalization debate. As Junek had cautioned, the period following the invasion became decisive in shaping — and hardening — attitudes among Slovaks and Czechs, causing national stereotypes to become intractable.

In the meantime, the invasion and normalization brought major setbacks for Slovak cartoonists. The occupation authorities closed Kultúrny život, which was not revived until after the Velvet Revolution more than twenty years later. And even though surviving publications like Roháč and Smena continued to offer space to cartoonists, the range of permissible political satire narrowed considerably. Furthermore, many Slovak cartoonists lost their jobs and their cartoons disappeared from the pages of the Slovak press. Stano Kochan left Czechoslovakia after the invasion and began contributing cartoons to Pardon, a publication in Frankfurt. Back in Czechoslovakia, the normalization regime forced Dušan Junek to relocate to the eastern reaches of Slovakia, where he had to abandon his studies and give up his work as a cartoonist. Marián Vanek met a similar fate, since the Communist government barred him from public exhibition after 1969 on the bogus allegation that his work had turned pornographic. Deprived of his career as a cartoonist, Vanek bounced from job to 


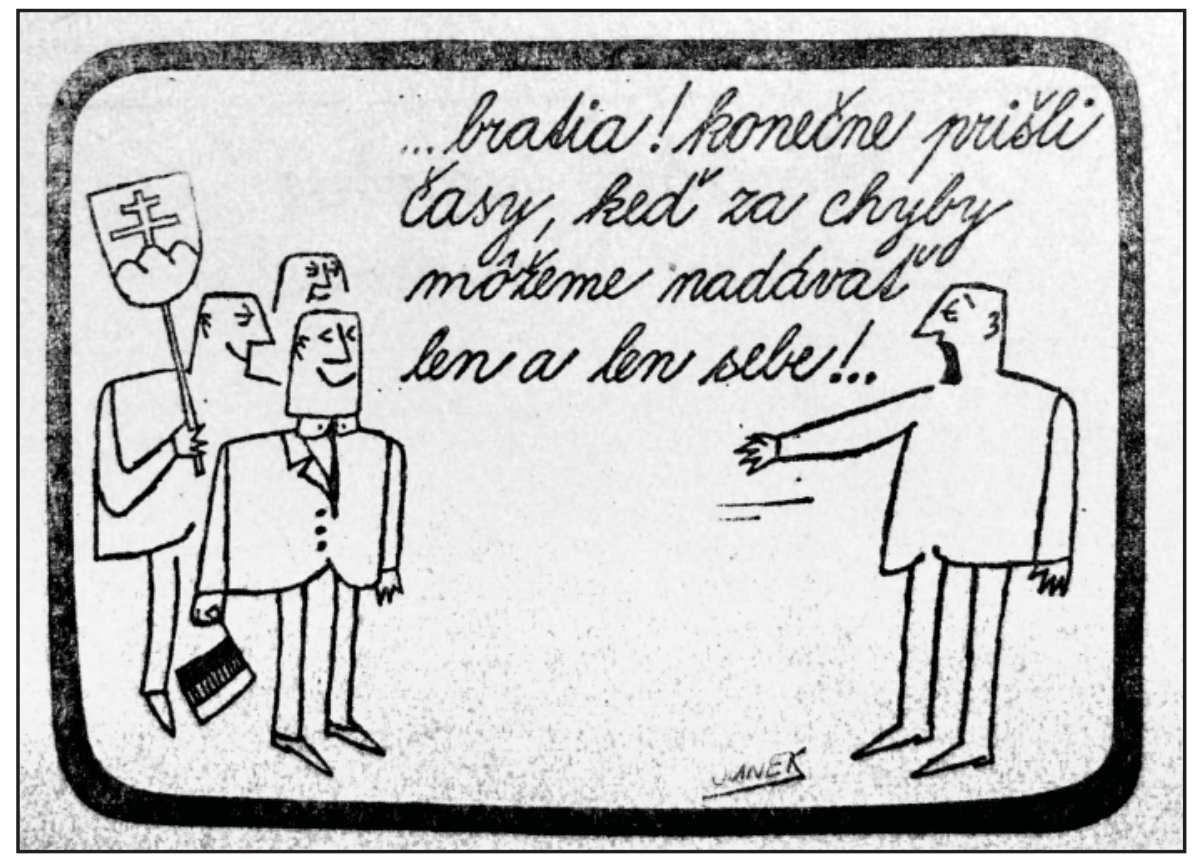

Figure 43: Dušan Junek, "Brothers! The time has finally come when we only have ourselves to blame for mistakes!” Smena, 28 October 1968. 
job around Slovakia until the authorities sent him to Šumava, a forested region in the southwestern edge of Bohemia, as far removed from Slovakia - and his Slovak audience — as Vanek could be while remaining in Czechoslovakia. ${ }^{28}$ With the end of the Czechoslovak Spring and the onset of normalization in the period following the invasion, a golden age of Slovak cartooning came to a close. Slovak cartoonists would have to wait until the collapse of communism in 1989 for their next chance to practice their craft without political restraints.

\section{Lessons from Cartoons after Communism}

The outbreak of the Velvet Revolution and the rapid collapse of the Communist regime in late 1989 seemed to many Slovaks and Czechs that their dreams from 1968 had come true at last. In a cartoon from December 1989, František Mráz shows the Velvet Revolution - 1989 — as the resumption of the Czechoslovak Spring - 1968 and its quest for democracy following a twenty-one year interruption (figure 44). For Slovak cartooning, the triumph of democracy in 1989 brought a revival much like the renaissance of Slovak political cartoons during the Czechoslovak Spring. Yet for all the similarities and continuities between these two seminal periods, Slovak cartoonists focused more attention on national, rather than democratic motifs, in contrast to 1968 . Yet this shift in thematic focus did not necessarily indicate a more nationalist turn for Slovak cartoonists and their audiences. In fact, most Slovak cartoonists active in the years immediately following the Velvet Revolution continued to portray extreme Slovak nationalism and separatism as objects of ridicule.

The greater concern Slovak cartoonists showed for federal reform and other national grievances after the fall of communism also offers clues to the importance of surrounding circumstances in shaping the content of their cartoons during the Czechoslovak Spring. In particular, the increased frequency of national themes after 1989 attested to the importance of the changed context. Slovak cartoonists of the early 1990s could devote more attention to national demands because democracy had become more secure in Czechoslovakia. By contrast, democratic themes dominated Slovak political cartoons during the Czechoslovak Spring, and national motifs appeared much less often, because the fate of democratization remained uncertain. Slovak cartoonists' preoccupation with democratic subjects in 1968 reflected their hopes for the success of the reform movement, but also their anxieties about its possible defeat at the hands of domestic and foreign hard-liners. It was only when communism had become a dead letter after 1989 that Slovak cartoonists felt com- 


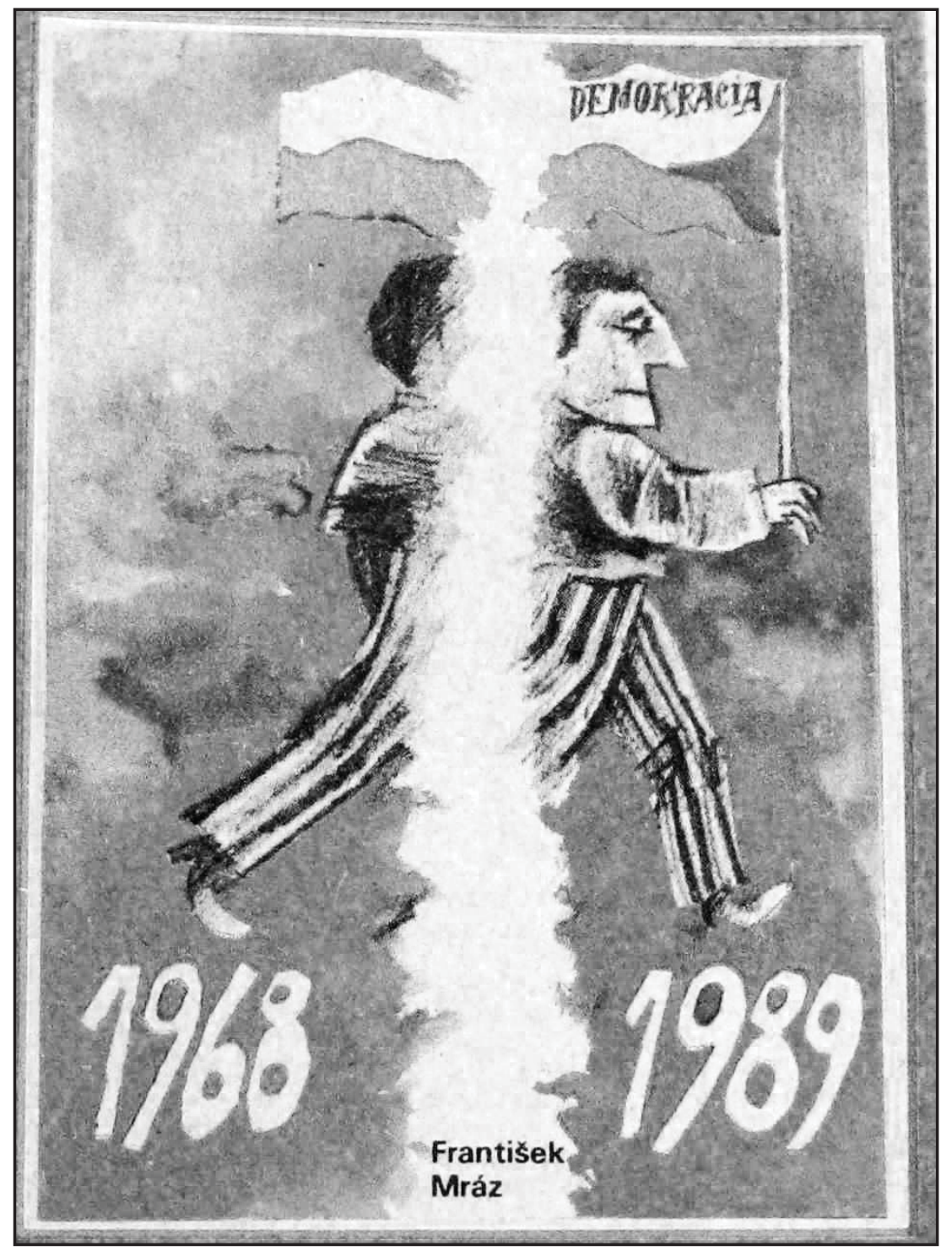

Figure 44: František Mráz, “Democracy 1968, 1989,” Roháč, 22 December 1989. 
fortable turning their attention to other important issues, including a restructuring of the existing federation to make it fairer and more equitable.

But perhaps most importantly, Slovak political cartoons offer a counterpoint to the misleading stereotypes of Slovaks during the upheaval of 1968. Foreign cartoons and scholarship on the Czechoslovak Spring have often made out Slovaks to be narrow-minded nationalists, especially in juxtaposition to the more liberal and democratic Czechs living beside them. Yet foreign observers and scholars appear merely to follow the lead of Czechs in reproducing such a national dichotomy. In 1968, Czech political cartoonists almost completely ignored Slovaks' concerns for national equality and fairness while Czech intellectuals second-guessed Slovaks' commitment to democratization. ${ }^{29}$ But as Slovak political cartoons from the Czechoslovak Spring show, many Slovaks valued democratization above narrowly national demands, and even those cartoons that addressed issues like federalization were always careful to depict such a resolution of the Slovak question as a matter of democratization.

Thus, Slovak political cartoons from 1968 are valuable as a corrective to stereotypes about Slovaks during and after the Czechoslovak Spring. Even though many Slovaks called for the redress of perceived wrongs against the Slovak nation, their demands stemmed less from national egotism and chauvinism than from a deep-seated desire to see basic democratic principles of fairness and equality applied consistently to relations between Czechoslovakia's titular nations. Accordingly, Slovak cartoonists portrayed national grievances as legitimate when they invoked such democratic precepts, while they also used satire to mock Slovaks who subordinated national demands to democratization in order to discredit such an overly nationalist agenda. A concern for democracy underpinned Slovak political cartoons from this period, and it led prominent Slovak cartoonists to caution their audiences against reducing democratization to federalization at the height of the Czechoslovak Spring, and to alert Slovaks to the dangers of letting their national concerns to derail democratization. Ironically, then, Slovak cartoonists' caricatures of Slovak national demands present a more complex and nuanced image of Slovak attitudes in 1968 than the interpretations of Czechs and others have allowed. 


\section{Notes}

1. A shakeup in the political leadership in Slovakia in 1963 brought a relaxation of political controls that made the Slovak press freer than its Czech counterpart. For instance, Kultúrny život, the weekly magazine of the Union of Slovak Writers, published critical articles by both Slovak and Czech authors too hot for the Czech press to handle. As a result, Kultúrny život became the first Slovak publication to develop a sizable following among Czech readers. In turn, the limited availability of Kultúrny život in the Czech Lands led to a thriving resale market for secondhand copies that sold for several times the cover price. Eugen Steiner, The Slovak Dilemma (Cambridge: Cambridge University Press, 1973), 121; Juraj Fabian, “Analýza masových oznamovacích protriedkov (1967-70), " in Slovenská spoločnost'v krizových rokoch 1967-1970, vol. 2 (Bratislava: Komisia vlády SR pre analýzu historických udalostí z rokov 1967-1970 and Politologický kabinet SAV, 1992), 127-128.

2. For one such example of this dismissive view of Slovaks' commitment to democratization, see Vladimír V. Kusin, Political Grouping in the Czechoslovak Reform Movement (New York: Columbia University Press, 1972), 143-149. Likewise, Galia Golan presents the disputes between Slovaks and Czechs during the Czechoslovak Spring as a conflict between Slovaks interested in federalization and Czechs concerned with democratization. See Galia Golan, Reform Rule in Czechoslovakia: The Dubček Era, 1968-1969 (Cambridge: Cambridge University Press, 1973), 186-199.

3. For a lengthier discussion of the function of revolutionary media in challenging cultural hegemony, see Juanita Darling, Latin America, Media, and Revolution: Communication in Modern Mesoamerica (New York: Palgrave Macmillan, 2008), 7-10. The importance of crisis in enhancing the social impact of cartoonists is discussed in Chris Lamb, Drawn to Extremes: The Use and Abuse of Editorial Cartoons (New York: Columbia University Press, 2004), 4, 61-62.

4. Though cartoonists often include text, either in explanatory captions or as part of the cartoon itself, their images also appeal to the sense of sight in a way text alone cannot, allowing cartoons to resonate even with the illiterate. Sensory appeal also helps to grab the reader's attention and identify with the cartoon's message. James A. Leith, Media and Revolution: Moulding a New Citizenry in France during the Terror (Toronto: CBC Publications, 1968), 32; Lamb, Drawn to Extremes, 25; Walter Lippmann, "Newspapers," in Media Power in Politics, ed. Doris A. Graber, $5^{\text {th }}$ ed. (Washington, D.C.: CQ Press, 2007), 51.

5. Darling, Latin America, Media, and Revolution, 14-15; and Annabelle Sreberny-Mohammadi and Ali Mohammadi, Small Media, Big Revolution: Communication, Culture, and the Iranian Revolution (Minneapolis: University of Minnesota Press, 1994), 24.

6. Milan Šimečka, “Čas satiry,” Listy, 27 February 1969.

7. Kornel Földvári, Pät’advadsat': Kniha o slovenskej karikatúre (Levice: Koloman Kertész Bagala, 2005), n.p. 
8. In 1968, Smena had a circulation of 172,669, Práca's circulation was 170,370, and Pravda's was 278,750. Kultúrny život had a circulation of more than one hundred thousand, and it was the first Slovak publication to gain a significant foothold in the Czech Lands as well as in Slovakia. The circulation figures for newspapers come from Frank L. Kaplan, Winter into Spring: The Czechoslovak Press and the Reform Movement, 1963-1968 (Boulder, Colo.: East European Quarterly, 1977), 188. The circulation total for Kultúrny život is cited in Abby Innes, Czechoslovakia: The Short Goodbye (New Haven, Conn.: Yale University Press, 2001), 27.

9. In contrast to the KSS-published Pravda, cartoons never appeared in Rudé právo (Red Right), the KSC daily newspaper, not even during the brief period in 1968 when the Czechoslovak press had unprecedented license to publish whatever it wanted.

\section{Földvári, Pät'advadsat'.}

11. Cited and translated in Marína Zavacká, "Picturing 'the World Abroad': Official Domestic Propaganda in Czechoslovakia, 1956-1962," in Osteuropa vom Weltkrieg zur Wende, ed. Wolfgang Mueller and Michael Portmann (Vienna: Verlag der Österreichischen Akademie der Wissenschaften, 2007), 210, n. 2.

12. As Marína Zavacká observes in her study of Czechoslovak propaganda, politicians from nonaligned states on amicable terms with the socialist camp were the exception that proved the rule. Cartoonists could depict Patrice Lumumba or Fidel Castro as long as they were just maintaining friendly relations with the Communist countries. Yet the moment these leaders became formal allies of the socialist camp, their countenances disappeared altogether from Slovak and Czech caricatures. Zavacká, "Picturing 'the World Abroad," 210-211, 214.

13. When the KSČ-published humor magazine Dikobraz (The Porcupine), a Czech analogue to Roháč, printed Jaroslav Malák's caricatures of four hard-line politicians on the cover in March 1968, the editors alerted their readers to the importance of this development. In a front-page letter addressed to the readers of Dikobraz, the editors explained how Malák's cartoon was "historic" since it was the first time in the magazine's twenty-year history that Dikobraz had published a caricature critical of prominent Communist politicians. Dikobraz, 28 March 1968.

14. The cartoons of Marián Vanek from this period best capture this tendency, since Vanek depicts all his cartoon figures with identical features, relying on contextual elements like setting, clothing, and text to convey the cartoon's message.

15. Jiří Pernes, Dějiny Československa očima Dikobrazu, 1945-1990 (Brno: Barrister \& Principal, 2003), 141.

16. The five Warsaw Pact states that pressured Czechoslovakia to curtail the reforms of the Czechoslovak Spring and ultimately intervened militarily were the Soviet Union, Poland, East Germany, Hungary, and Bulgaria. In popular discourse in Czechoslovakia in 1968, these countries became known simply as "the Five." 
17. So tense was the atmosphere that the Soviet delegation had refused to meet in the larger eastern Slovak city of Košice, or even to spend the night on Czechoslovak soil. Instead of staying in Slovakia, the Soviet delegation's special train withdrew across the border into the Soviet Union at the end of each day's talks.

18. For a more extensive discussion of the issues and attitudes at work in the federalization debate, see Scott Brown, "Socialism with a Slovak Face: Federalization, Democratization, and the Prague Spring," East European Politics and Societies 22, no. 3 (Summer 2008): 467-495.

19. Ladislav Vrtel', Osem storoči slovenskej heraldiky/Eight Centuries of the Slovak Heraldry (Martin and Wauconda, Ill.: Vydavatel'stvo Matice slovenskej and Bolchazy-Carducci Publishers, 1999), 212-214.

20. Zákon ze dne 17. listopadu 1960 o státním znaku a o státní vlajce, Law 163, Collection of Laws 1960, Part 18, 17 November 1960. The law is available online from the Ministry of the Interior of the Czech Republic at http://aplikace.mvcr.cz/archiv2008/sbirka/1960/sb70-60.pdf (accessed 2 March 2010).

21. "Informácia o rezolúciach a listoch došlých Predsedníctvu Slovenskej národnej rady v súvislosti s Vyhlásením SNR z 15. 3. 1968 ako aj k Akčnému programu KSČ," 10 June 1968, Slovak National Archive, Presidium of the Slovak National Council, carton 167.

\section{Jozef Novák, “Nový štátny znak,” Pravda, 31 May 1968.}

23. Slovak national organs (including the Slovak National Council and the separate Communist Party of Slovakia) were vestiges of Slovakia's wartime independence. No Czech analogues existed. Instead, statewide Czechoslovak organs performed double duty as Czech national organs, which were thus formally superior to Slovak national organs. This uneven institutional arrangement came to be known as "asymmetry," leading pro-reform Slovaks to demand "symmetry" along with federalization in order to rectify the Slovak nation's subordinate position and thus give the Czechoslovak state a more democratic structure. See Brown, "Socialism with a Slovak Face."

24. Conversely, many Czechs resented Slovak demands for federal reform during the Czechoslovak Spring, and especially after the collapse of communism, because they thought the Czech Lands had subsidized the economic and cultural development of Slovakia and felt Slovaks were being ungrateful despite having benefited unequally from the common state. These mutual perceptions of one nation profiting at the expense of the other engendered considerable ill will in 1968 and contributed to the Czech-Slovak conflicts that helped to split the state in the early 1990s.

25. Brown, "Socialism with a Slovak Face," 471-472.

26. The notion that a breakup of Czechoslovakia, though unwanted, would at least bring a welcome resolution to the Slovak question was not farfetched. The idea of "relief" resurfaced in 1992, when discussions over the fate of the federation finally collapsed and Slovak and Czech 
politicians began to plan the peaceful disintegration of the country. See, for instance, the Czech sigh of "relief" that the impasse had finally been broken in "Úleva z rozhodnutí," Literární noviny, 18-24 June 1992.

27. Anton Hollý, "Drahí čitatelia Roháča,” Roháč, 18 September 1968.

28. Földvári, Pätadvadsat'.

29. The lack of Czech enthusiasm for federalization was understandable, since Czechs stood to lose decision-making power under a federal arrangement. 
Center for Russian \& East European Studies

University Center for International Studies

University of Pittsburgh

4400 W. W. Posvar Hall

230 South Boquet Street

Pittsburgh, Pennsylvania 15260

(412) 648-8716

www.ucis.pitt.edu/crees/cbpaper.html.

Ronald Linden, Bob Donnorummo, William Chase, Andrew Konitzer, Co-Editors Eileen O’Malley, Managing Editor

Julie Tvaruzek, Editorial Assistant 